\title{
Brook trout (Salvelinus fontinalis) movement and habitat use in a headwater stream of the central Appalachian Mountains of West Virginia
}

\author{
Marisa Nel Logan \\ West Virginia University
}

Follow this and additional works at: https://researchrepository.wvu.edu/etd

\footnotetext{
Recommended Citation

Logan, Marisa Nel, "Brook trout (Salvelinus fontinalis) movement and habitat use in a headwater stream of the central Appalachian Mountains of West Virginia" (2003). Graduate Theses, Dissertations, and Problem Reports. 1798.

https://researchrepository.wvu.edu/etd/1798

This Thesis is protected by copyright and/or related rights. It has been brought to you by the The Research Repository @ WVU with permission from the rights-holder(s). You are free to use this Thesis in any way that is permitted by the copyright and related rights legislation that applies to your use. For other uses you must obtain permission from the rights-holder(s) directly, unless additional rights are indicated by a Creative Commons license in the record and/ or on the work itself. This Thesis has been accepted for inclusion in WVU Graduate Theses, Dissertations, and Problem Reports collection by an authorized administrator of The Research Repository @ WVU. For more information, please contact researchrepository@mail.wvu.edu.
} 
Brook Trout (Salvelinus fontinalis) Movement and Habitat Use in a Headwater Stream of the Central Appalachian Mountains of West Virginia

\author{
Marisa Nel Logan
}

\author{
A Thesis \\ Submitted to \\ The College of Agriculture, Forestry, and Consumer Sciences \\ at \\ West Virginia University \\ In partial fulfillment of the requirements \\ for the degree of \\ Master of Science \\ In \\ Wildlife and Fisheries Resources \\ Kyle J. Hartman, Ph.D., Chair \\ Stuart A. Welsh, Ph.D. \\ J. Todd Petty, Ph.D. \\ Wildlife and Fisheries Program of the Division of Forestry \\ Morgantown, West Virginia \\ 2003
}

Keywords: Brook Trout, Habitat, Movement 


\section{$\underline{\text { Abstract }}$ \\ Brook Trout (Salvelinus fontinalis) Movement and Habitat Use in a Headwater Stream of the Central Appalachian Mountains of West Virginia Marisa Nel Logan}

Brook trout (Salvelinus fontinalis) are the only salmonid native to the Appalachians. They are a resilient species, populating small, low productive streams. Although such streams have historically been abundant in the Appalachians, brook trout populations have been threatened due to habitat degradation such as logging and acidification of waters. The objective of this study was to evaluate brook trout habitat use, home range, and movement patterns in an Appalachian headwater stream during spring and more specifically high flow events. I implanted brook trout with radio tags and tracked their movement for approximately 30 days during late spring 2002 and early spring 2003. The hypotheses tested were as follows; 1) There is no difference between habitat used by brook trout and available habitat, 2) High flow events have no affect on brook trout habitat selection or movement, 3) Spatial structure of preferred habitat does not influence movement. The results of my research showed that brook trout used pools as their primary habitat and that large woody debris was used as cover and as a pool forming structure more than what can be expected by chance. Other habitat variable use such as water depth and velocity were artifacts of pool use. Results also showed that brook trout were very mobile, moving hundreds of meters in one day. 


\section{Acknowledgements}

I would like to thank the members of my graduate committee, Dr. Kyle J. Hartman, Dr. Stuart A. Welsh, and Dr. J.Todd Petty. A great deal of thanks goes out to John Sweka, Jeremy Webster, Ben Lenz, Keith Cox, John Howell, Jason Freund, Kim Bjorgo, Dr. Kyle J. Hartman, Donna Hartman, and Terry Jenkins for their assistance in the field. I'd like to thank John Sweka for his statistical support. Special thanks goes out to my husband, David Logan for his love and support. Another special thanks goes out to my mother for her love, support, and baby sitting. I'd also like to thank the support of MeadWestvaco Inc. Funding for this project was provided by the United States Forest Service. 


\section{Table of Contents}

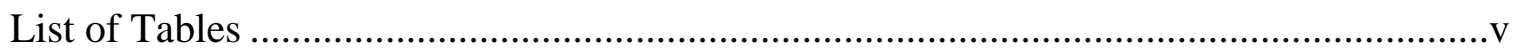

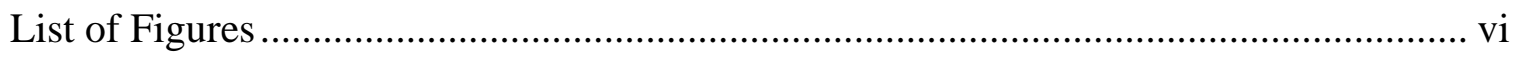

Chapter 1: Introduction .......................................................................................

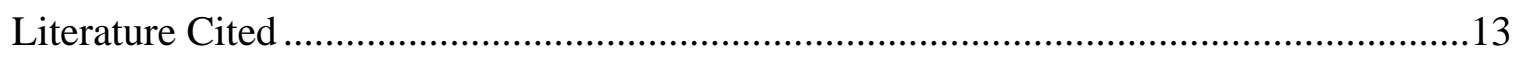

Chapter 2: Brook Trout (Salvelinus fontinalis) Movement and Habitat Use in a Headwater Stream of the Central Appalachian Mountains of West Virginia

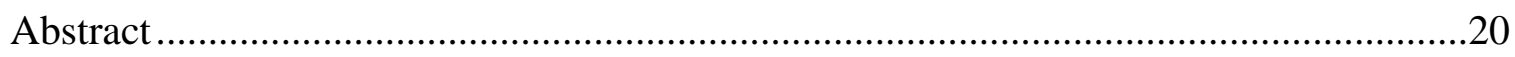

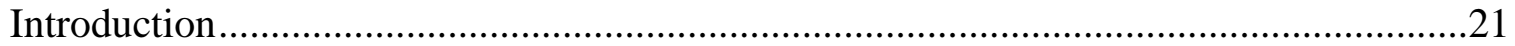

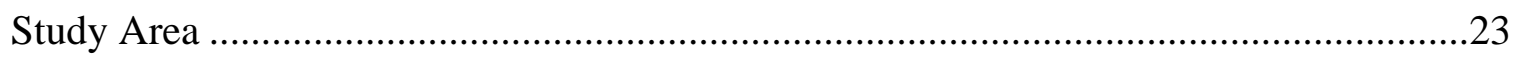

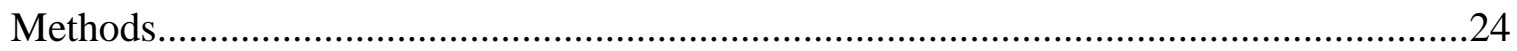

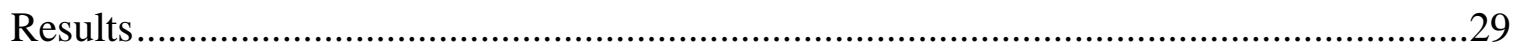

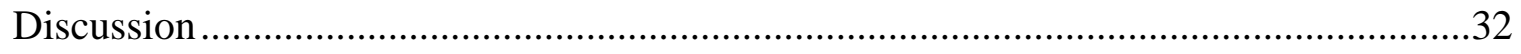

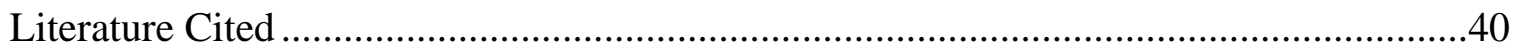

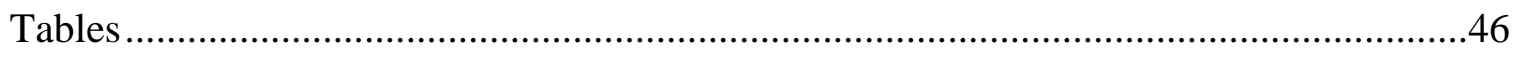

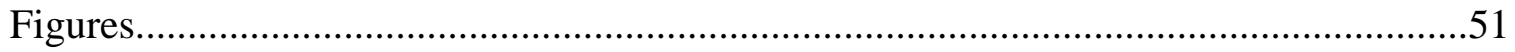

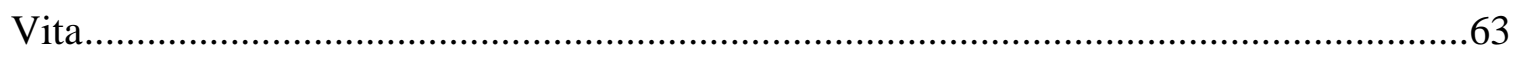




\section{List of Tables:}

Table 1. Location and movement data for the first season of tracking (May 14June 20, 2002) for each fish determined by tag frequency.

Table 2. Location and movement data for the second season of tracking (March 27- May 8,2003 ) for each fish determined by tag frequency.

Table 3. Habitat variable use for the first season of tracking (May 14-June 20, 2002) compared to available habitat in Birch Fork.

Table 4. Habitat variable use for the second season of tracking (March 27- May 8, 2003) compared to available habitat in Birch Fork.

Table 5. Habitat variable use for high flow $\left(>0.35 \mathrm{~m}^{3} / \mathrm{s}\right)$ and non-high flow events from second season (2003). High flows were determined as the $75^{\text {th }}$ percentile of all daily discharge measurements. 


\section{List of Figures:}

Figure 1. The Birch Fork study site part of the Middle Fork River Watershed,

Randolph County, West Virginia.

Figure 2. Discharge measurements at the lower study reach of Birch Fork during the 2002 and 2003 tracking season.

Figure 3. Histogram of total distance moved by brook trout in Birch Fork during the 2002 and 2003 tracking period.

Figure 4. Histogram of home range lengths for brook trout in Birch Fork during the 2002 and 2003 tracking period.

Figure 5. Brook trout use vs. available primary habitat during 2002 and 2003 tracking. 55

Figure 6. Brook trout use vs. available pool forming structures during 2002 and 2003 tracking 56

Figure 7. Brook trout use vs. available cover type during 2002 and 2003 tracking.

Figure 8: Net movement histogram for the 2002 and 2003 tracking season. Negatives values represent a net down stream movement and positive values represent a net up stream movement.

Figure 9: Percent primary habitat use at varying discharge. 59

Figure 10: Primary habitat use for 2002 and 2003 broken down by individual fish versus where they were first placed in Birch Fork.

Figure 11: Individual fish net movement (2002 and 2003) compared to where they were originally placed in Birch Fork.

Figure 12: There was no link between section length (representing habitat complexity) and movement 


\section{Chapter 1:}

\section{Introduction}

Brook trout (Salvelinus fontinalis) are the only salmonid native to the Appalachians and are a very popular game fish in West Virginia. The native brook trout of the central Appalachian Mountains are relatively small $(<250 \mathrm{~mm})$ compared to other portions of their range (250-350 $\mathrm{mm}$ ), but they are a very resilient species, populating small, low productive stream systems (Ensign et al. 1990). Although there are a multitude of small streams that historically supported brook trout in the Appalachians, their populations have declined and many current populations are threatened (DeWald and Wilzbach 1992, Ensign et al. 1990, Menendez et al. 1996). Much research has been conducted on brook trout populations and the main cause for their perceived decline has been attributed to habitat degradation.

\section{Habitat Degradation}

In West Virginia brook trout habitat degradation is caused by the combination of logging, acidity, and to a lesser extent agriculture. In larger systems, streams were channelized to aid in the transport of logs, which removed instream habitat, such as boulders, large woody debris (LWD) and spawning gravel (Meehan 1994). Logging also adds sediment to the stream primarily from associated roads (Hartman 1996, Eaglin et al. 1993) and extensive bulldozer use (Burns 1972). Eaglin et al. (1993) found trout populations were negatively related to culverts, which are often required by logging roads. Eaglin et al. (1993) also found a positive relationship between culvert density and fine sediment and embeddedness, which is negatively related to brook trout reproduction success in Appalachian streams (Hakala 2000). Increased sediment and turbidity, another result of logging (Burns 1972), often become a problem during high flows and may result in reduced foraging efficiency in brook trout (Sweka and Hartman 2002). 
Many studies have proven large woody debris $(>10 \mathrm{~cm})$ to be a very important element in trout streams. It has an affect on depth, current, substrate composition and channel morphometry. Intensive logging often removes much of the potential source of large woody debris to streams (Hairston-Strang and Williams 1998). Removal of LWD has also been linked to high mean-flow velocity and flood events (Gippel 1995). Hilderbrand et al. (1997) reported the presence of LWD increased the number of pools, and the complexity within these pools (Harvey 1998). LWD also increases invertebrate production by providing habitat and accumulating organic storage (Angermeier and Karr 1984, Cederholm et al. 1997, Bisson et al. 1987). Angermier and Karr (1984) reported habitat with LWD supported four times the invertebrate biomass than areas lacking LWD. Removing terrestrial vegetation and LWD from the area immediately surrounding the stream can cause increases in stream temperature (Swift and Messer 1971, Golladay and Webster 1988), which may prove lethal $\left(>25.4^{\circ} \mathrm{C}\right)$ to brook trout (Fry et al. 1946, Burns 1972, Elliott 2000). Angermeier and Karr (1984) found that removal of LWD from the stream caused decreases in stream depth profiles and in pool formations. Rosenfeld et al. (2000) discovered pools formed by LWD were 10\% deeper than those formed by other means, and Harvey (1998) observed an increase in coastal cutthroat trout (Oncorhynchus clarki clarki) residency rates associated with such pools.

Studies have been conducted on how agriculture affects trout habitat. Matthews (1996) reported that trout avoided bare banks and collapsed banks, which are characteristic of cattle grazing. Cattle also damage sedge, which is also preferred by trout as cover (Matthews 1996, Wohl and Carline 1996). During a study on several Pennsylvania streams Wohl and Carline (1996) found there to be a significantly greater amount of silt and sand in streams affected by 
grazing, and also a lack of overhanging vegetation. Low gradient streams are often affected by clearings and channelization for agriculture purposes (Angermeier and Karr 1984).

Not only does sediment enter the stream in many different ways, but the USEPA (1996) considers it the most prevalent form of water quality degradation. Sediment can cause many problems including interference with trout reproduction. Fine sediment fills in interstitial space within spawning gravel which prevents hatching fry from escaping and causes mortality (Phillips et al. 1975, Witzel and MacCrimmon 1981). Hillman et al. (1987) reported addition of large amounts of sediment caused a loss of pool habitat in a highly sedimented stream in Idaho. Fine sediment also prevents water flow from delivering intragravel dissolved oxygen (IGDO) to the embryos, which may also cause mortalities (Maret et al. 1993), or a reduction in growth (Silver et al. 1963). Sowden and Power (1985) conducted a study that concluded rainbow trout (Oncorhynchus mykiss) embryo survival strongly depends on dissolved oxygen (DO) content in redds. Continuous additions of fine sediment can also alter food levels for trout through a negative effect on aquatic invertebrate populations (Hawkins et al. 1983, Hartman et al. 1996). Sediment can also cause increased turbidity. Turbidity in turn can affect a trout's ability to detect predator and prey (Miner and Stein 1996, Gregory 1993, Sweka and Hartman 2002) and may alter its activity and cover use (Gradall and Swenson 1982), or reduce growth rates (Sweka and Hartman 2002).

Rainfall is naturally acidic (carbonic acid), but most of the harm is done by acid rain originating from industrial pollutants, mainly sulfates and nitrates. Adding to this decrease in $\mathrm{pH}$ is acid mine drainage (AMD). The problem of low $\mathrm{pH}$ occurs most often in poorly buffered streams, during high flows (Sharp et al. 1984). This can cause a reproductive trap by allowing brook trout to spawn during base flows with acceptable $\mathrm{pH}$. Then when the next rain event 
occurs, a drop in the pH causes egg mortalities (Lamothe 2002). Menendez et al. (1996)

suggested that individual brook trout can survive acidic episodes lasting under 24 hours. Low pH is frequently accompanied by high concentrations of aluminum. Gagen et al. (1994) found both these conditions to cause increased brook trout mortality. Acidification affects mostly the early life history stages of brook trout, leaving behind a population of mostly large fish (Haines 1981). A study conducted by Jordahl and Benson (1987) reported low pH caused incomplete hatching of brook trout eggs and reduced larval activity and pigmentation. Low $\mathrm{pH}$ can also affect foraging by decreasing the amount of available macroinvertebrates (Krueger and Waters 1983).

Research on brook trout habitat degradation has identified problems, but it has also revealed many effective management practices. Clayton et al. (1998) studied the results of adding limestone in different forms to several acidic West Virginian streams. Their results showed fish popuations expanded in species composition and biomass in limed streams. They determined limestone is best added in the form of sand. Sand can be added to a stream at a single location as far upstream as possible. It also should be applied during the dry season to accommodate vehicles. Clayton et al. (1998) also suggests the initial treatment be twice the annual estimation. There have been no biological problems found due to the dissolved and suspended limestone being in the stream (Downey et al. 1994, Menendez et al. 1996, Clayton et al. 1998). Lacroix (1992) also found that the addition of crushed limestone benefited both the spawning activity and abundance of salmon and brook trout in an acidic stream in Nova Scotia. Overall, Clayton et al. (1998) concluded that "instream limestone sand is the most cost-effective method available to fishery managers to counteract the effects of acid deposition and restore the biological integrity of affected streams”. The addition of limestone sand by the combined efforts of the West Virginia Department of Natural Resources (WVDNR) and the West Virginia 
Department of Environmental Protection (WVDEP) has solved many of the problems with water quality in West Virginia associated with low pH (Menendez et al. 1996).

Streamside management zones (SMZ’s) have been established to try to protect the area surrounding streams from logging. According to WV best management practices (BMP’s), only $50 \%$ of the basal area within an SMZ can be taken by loggers. MeadWestvaco's logging policy is to only use $30 \%$ of the basal area (Eldon Plaugher, MeadWestvaco Inc., personal communication). Bopp (2002) suggests opening the canopy of the riparian zone by way of low impact tree removal to increase macroinvertebrate abundance. Other benefits may be gained by actually leaving felled tree tops in the stream to possibly increase deep water pools (Lamothe 2002). Many other improvements have been made in logging practices including seeding disturbed areas with grass and building roads away from streams (Burns 1972). Habitat manipulation in the form of added LWD has helped with the problems associated with the removal of riparian wood. Gowan and Fausch (1996) found the addition of LWD increased trout abundance. Putting up fences around trout streams to restrict access by cattle has helped manage low-gradient streams affected by grazing (Matthews 1996).

\section{Movement}

Stream fish movement depends on several factors, including water quality, spawning, food availability and suitable habitat. Aside from movement during the spawning season, location of preferred habitat drives most of their movement. Water quality and food availability are both closely interrelated with habitat selection. Gagen et al. (1994) recorded downstream movement by brook trout during episodes of low $\mathrm{pH}$ and high concentrations of Al. Stream salmonids, such as brook trout, seek habitats where both maximum net energy gain and protection from predators are met (Fausch 1984). When such a habitat cannot be found it is 
expected that the trout will continue its movement. This can cause the fish to weaken, and lower its chances of survival.

High flows may cause fish to move as they seek refuge from the increased discharge and velocity. Obviously the stronger the current the fish has to swim against, the more energy it expends. High flows produce increases in depth, velocity and especially sediment load (Leopold, 1994). The added turbidity caused by high flows may also add reason to a fish’s movement (Sweka and Hartman 2002).

The degree of movement of a fish in and out of an area may be a good indicator of habitat quality. Areas of low habitat quality should tend to have a high turnover of fish and an area of high habitat quality should have a low turnover of fish (Winker et al. 1995, Harvey 1998). Resident trout have been considered immobile (Gerking 1959, Matthews 1996). The lack of movement in some trout populations may actually be due to frequent barriers within the stream (Thompson and Rahel 1998). In more recent studies, especially ones using radio telemetry, brook trout, brown trout (Salmo trutta) and coastal cutthroat trout have been found to cover quite large distances (Young 1995, Harvey 1998, Gowan and Fausch 1996). This difference may be due to methods. A mark-recapture study may consider fish not recaptured as mortalities when they may simply have moved out of the study area (Young 1996). Radio telemetry can often provide better information on fish locations and the distance they move than other methods.

\section{Telemetry}

There are generally two types of underwater biotelemetry, ultrasonic and radio. Although telemetry studies are expensive, it is the most practical way to measure individual fish movements and microhabitat preferences. Both forms of telemetry provide additional data that is 
not available through mark/recapture studies, and it is also less invasive when actual data collection begins. Other than the initial implantation surgery, tracking has little influence on the behavior of fish and recovery from surgery is relatively short (Hart and Summerfelt 1975, Matthew 1996).

Choosing between ultrasonic and radio telemetry for an underwater study depends mostly on the study area. Ultrasonic transmitters were developed first for use in underwater biotelemetry due to their low frequency and long-wave signals (Winter 1983). These characteristics make ultrasonic transmitters most useful in water with high conductivity, such as salt water and any deep water. The signal, however, is negatively affected by algae, thermoclines, boat motors and bubbles from turbulent water. Individual ultrasonic transmitters are depicted by a difference in pulse-rates, minimizing the number of distinguishable individuals.

Radio transmitters were originally developed for terrestrial animal use, but were modified for water studies in the late 1960's (Winter 1983). Radio transmitters work best in shallow, low conductivity water. Radio signals are not affected by algae, thermoclines, boat motors or bubbles, and because the receiver does not have to come in contact with the water, a greater area can be sampled in a shorter period of time. Radio transmitters also transmit a different frequency from each tag making identification of individuals easy. However, radio transmitters can not be used in saltwater or deep water due to attenuation of signals (Winter 1983, Freund and Hartman 2002). Radio signals can also be deflected by metal, trees, and boulders making detailed tracking difficult. However this can be overcome with tracking experience. So, for a study in a mountain stream on brook trout, radio telemetry would be best.

With advances in telemetry technology and smaller transmitters available, more and more studies are using surgically implanted transmitters in stream fish compared to other methods of 
monitoring fish movement. Attaching transmitters externally is usually not feasible for stream fishes due to drag, imbalance, and chance of entanglement. Stomach placement of transmitters also has its drawbacks, due to feeding alterations and regurgitation (Hart and Summerfelt 1975). Surgically implanted tags have much higher retention and the long thin antenna trailing behind the fish is sometimes the only external evidence of the tag. Through radiotelemetry studies and assessment of available habitat, trout habitat preferences are more easily defined, and the role of preferred habitat availability on movement better assessed.

\section{Habitat Selection}

Most trout habitat studies agree that stream-dwelling trout prefer pool habitat (Flebbe and Dollof 1995, Young 1995, Berg et al. 1998, Bunnell et al. 1998). There are many different kinds of pools including dammed pools, plunge pools, backwater pools, lateral scour pools, straight scour pools, step pools and trench pools. These are formed by the act of erosion around boulders, rootwads, and LWD (Bozek and Rahel 1991). Rosenfeld and Boss (2001) concluded that both juvenile and larger cutthroat trout (Oncorhynchus clarki) prefer deep pools, but only the adults require pools. They reported that adult cutthroat trout were generally not found in riffles because they experienced a negative growth rate, whereas the young of the year (YOY) were capable of growth in riffle habitats. Although YOY prefer pools, they are usually found in riffles due to competitive or antagonistic interaction with larger trout. Fish occupy the best area they can defend (Hughes 1998) and experiments show that the size of the fish is usually the deciding factor (Rosenfeld et al. 2000).

A study done by Elliott (2000) investigated the importance of pools during summer droughts. He had found that brown trout (Salmo trutta) were forced into pools by the lack of water, which also prevented migration. However not all pools were a sufficient refuge. The 
majority of brown trout were found in deep pools that retained a viable temperature $\left(<25^{\circ} \mathrm{C}\right)$ (Fry et al. 1946). Elliott (2000) also found that brown trout selected bottom pool layers with low temperature and low oxygen over upper layers with higher temperatures and higher oxygen. Reeves et al. (1991) reviewed studies on habitat rehabilitation where fish became more abundant due to an increase in the number, size and depth of pools, especially in drought stricken streams. Pool formations are also extremely important in that they provide protection from predators (avian and terrestrial) and high flow events (Cederholm et al. 1997, Bisson et al. 1987, Elliott 2000, Rosenfeld and Boss 2001, Bozek and Rahel 1991).

Although pools have proven to be a very important trout habitat, a need for habitat complementation has also been found to be very important. Habitat complementation refers to the different habitats that a trout must move between in order to obtain necessary resources or to complete its life cycle (Schlosser 1995). For a brook trout, as well as all organisms, these requirements include habitat for feeding, spawning and refuge (Schlosser 1995). Since each of these resources is generally found in different types of habitat, a fish may have to travel long distances to reach each of them, depending on their proximity. In the fall, female brook trout search for microhabitat with appropriate features for spawning. These features include gravel and either non-acidic, oxygenated water or areas of groundwater upwelling (Benson 1953). Hakala (2000), Beard and Carline (1991) and Benson (1953) concluded availability of spawning habitat was positively correlated with population densities. After spawning, brook trout must prepare themselves for harsh winter temperatures by finding refuge in deep pools to decrease energy expenditure (Cunjak 1996, Heifetz et al. 1986). The arrival of spring offers the brook trout the opportunity to resume more active foraging. Brook trout forage typically in areas of slow current immediately adjacent to fast current (Baker and Coon 1997). 
Since the idea of habitat complementation seems to be such an important component of the brook trout life cycle, then protecting or reestablishing this stream complexity should be seriously addressed for management of brook trout populations. These habitats include headwater streams for spawning and juvenile refuge, and lower reaches for adult foraging and winter refuge. Considering this large scale, management must include the entire watershed (Lamothe 2002, Petty et al. in press).

However, there are other biotic factors that may interfere with how a brook trout selects its habitat. Other species, such as brown trout and rainbow trout have been shown to alter brook trout behavior. Fausch and White (1981) found that brown trout excluded brook trout from preferred habitat and shifted their resting positions. Studies have shown rainbow trout to alter brook trout distribution (Larson and Moore 1985) and even negatively affect juvenile growth (Rose 1986). Dewald and Wilzbach (1992) conducted a laboratory stream study in which they found brook trout exhibited a reduced feeding rate and often remained inactive on the streambed in the presence of brown trout. With the removal of rainbow trout, Lohr and West (1992) observed a change in brook trout location to more midstream positions.

Researchers have discovered many physical factors influencing salmonid abundance (Fausch et al. 1988, Scarnecchia and Bergersen 1987). Along with a preference for pools, brook trout have been known to also select deeper waters, slower velocities and habitat with cover. The deeper the average depth of a stream the higher the salmonid population is likely to be (Scarnecchia and Bergersen 1987). Lamothe (2002) found that residency rates for both juvenile and adult brook trout were dependent on water depth and availability of cover. Bozek and Rahel's (1991) study on habitat requirements of young Colorado River cutthroat trout (Oncorhynchus clarki pleuriticus) identified a need for low-velocity habitats. 
Not only is it important to compile data on what habitat brook trout use, it is also very important to find out what habitat is actually available to them. Habitat assessments are done many different ways and at many different degrees, but in order to assess habitat available to stream fish, a randomized methodology must be used. The most accurate way to inventory habitat would be to measure everything. This, however, is only practical in very small study areas.

There are generally two main procedures used to obtain habitat assessments. The first is the Representative Reach Extrapolation Technique (RRET). Using this technique allows a biologist to measure what they feel to be a representative reach and use those findings to extrapolate to the entire stream or even the watershed. Simonson et al. (1994) suggests using a natural feature of the stream, such as mean stream width (MSW) to determine reach length. This procedure is quite accurate for the stream the reach is in (Dolloff et al. 1993). One of the drawbacks to this is that the representative reach may not contain all habitat types available in the stream or watershed. Another is that there is no way of determining the precision or accuracy of the data produced by the RRET (Dolloff et al 1997).

The second procedure used to assess available habitat is the Basinwide Visual Estimation Technique (BVET). This procedure combines actual measurements and visual estimations. The visual estimations must be conducted by the same person throughout the study. Estimation bias can be corrected by applying a calibration ratio to all estimates (Hankin and Reeves 1988). This ratio is determined by actually measuring the variables approximately, every 5 estimations. Assuming the estimator is off by about the same amount each time, an average difference is then used to correct the estimated values. Uncommon features are more likely to be identified using the BVET. The BVET not only allows more habitats to be measured, it also surveys the habitat 
with known accuracy and precision (Dolloff et al. 1997). However, its drawback is that it does not allow detailed statistical information on hydraulic channel units (HCU's) (Petty et al. in press). Petty et al. (in press) suggests using a combination of both the RRET and BVET.

Determining the distance between transects is most commonly calculated using the MSW of the stream. Simonson et al. (1994) suggests using reaches 35 times the MSW with transects spaced 3 times MSW for narrow streams ( $<5 \mathrm{~m}$ wide) and 2 times MSW for wider streams (5-35 $\mathrm{m}$ wide). More frequent transects are needed in wider streams because they tend to have more variation than smaller streams. Using the information gathered from habitat assessments enables the management of stream fisheries and their habitat to be more targeted.

In this study, I will try to gain a better understanding of brook trout microhabitat selection in a headwater stream and how microhabitat availability influences movement of brook trout. To do so I have implanted brook trout with radio tags and tracked their movement for approximately 30 days during early summer 2002 and spring 2003. The purpose of this study is to determine microhabitat selection of brook trout in varying habitat complexity and how habitat complexity influences movement. The hypotheses being tested are as follows; 1) There is no difference between habitat used by brook trout and available habitat, 2) High flow events have no affect on brook trout habitat selection or movement, 3) Spatial structure of preferred habitat does not influence movement. 


\section{Literature Cited}

Angermier, P. L. and Karr, J. R. 1984. Relationships between woody debris and fish habitat in a small warmwater stream. Transactions of the American Fisheries Society 113: 716-726.

Baker, E. A. and Coon, T. G. 1997. Development and evaluation of alernative habiat suitability criteria for brook trout. Transactions of the American Fisheries Society 126: 65-76.

Beard, T.D. and R.F. Carline. 1991. Influence of spawning and other stream habitat features on spatial variability of wild brown trout. Transactions of the American Fisheries Society 120: 711-722.

Benson, N.G. 1953. The importance of groundwater to trout populations in the Pigeon River, Michigan. Transactions of the North American Wildlife Conference 18:268-281.

Berg, N., Carlson, A., and Azuma, D. 1998. Funcition and dynamics of woody debris in stream reaches in the central Sierra Nevada California. Canadian Journal of Fisheries and Aquatic Sciences 55: 1807-1820.

Bisson, P.A., et al. 1987. Large woody debris in forested streams in the Pacific Northwest, past, present, and future; Contribution no. 57. Streamside Management, Forestry and Fishery Interactions, E.O. Salo and T.W. Cundy, eds., Coll. Of Forest Resources, University of Washington, Seattle, Washington, 143-190.

Bopp, J. 2002. The combined effects of water chemistry, canopy cover, and basin area on benthic macroinvertebrates along a central Appalachian stream continuum. Master's Thesis. West Virginia University, Morgantown, WV.

Bozek, M.A. and F.J. Rahel. 1991. Assessing habitat requirements of young Colorado River cutthroat trout by use of macrohabitat and microhabitat analyses. Transactions of the American Fisheries Society 120:571-581.

Bunnel, D.B.Jr., Isely, J.J., Burrel, K.H., and Van Lear, D.H. 1998. Diel movements of brown trout in a southern Appalachian river. Transactions of the American Fisheries Society 127:630-663.

Burns, J.W. 1972. Some effects of logging and associated road construction on northern California streams. Transactions of the American Fisheries Society 101:1-17.

Cederholm, C. J., Bilby, R. E., Bisson, R. E., Bumstead, T. W., Fransen, B. R., Scarlett, W. J., and Ward, J. W. 1997. Responses of coho salmon and steelhead to placement of large woody debris in a coastal Washington stream. North American Journal of Fisheries Management 17: 947-964.

Clayton, J.L., E.S. Dannaway, R. Menendez, H.W. Rauch, J.J. Renton, S.M. Sherlock, and P.E. Zurbuch. 1998. Application of limestone to restore fish communities in acidified streams. North American Journal of Fisheries Management 18:347-360. 
Cunjak, R.A. 1996. Winter habitat of selected stream fishes and potential impacts from land-use activity. Canadian Journal of Fisheries and Aquatic Sciences 53(suppl. 1):267-282.

Dewald, Lynn, and M. A. Wilzbach. 1992. Interactions between native brook trout and hatchery brown trout: effects on habitat use, feeding, and growth. Transactions of the American Fisheries Society 121:287-296.

Dolloff, C.A., D.G. Hankin, and G.H. Reeves. 1993. Basinwide estimation of habitat and fish populations in streams. U.S. Forest Service General Technical Report SE-83.

Dolloff, C.A., H.E. Jennings, and M.D. Owen. 1997. A comparison of basinwide and representative reach habitat survey techniques in three Southern Appalachian watersheds. North American Journal of Fisheries Management 17:339-347.

Downey, D.M., C.R. French, and M. Odom. 1994. Low cost limestone treatment of acid sensitive trout streams in the Appalachian Mountains of Virginia. Water, Air and Soil Pollution 77:1-29.

Eaglin, G.S., W.A. Hubert. 1993. Effects of logging and roads on substrate and trout in streams of the Medicine Bow National Forest, Wyoming. North American Journal of Fisheries Management 13:844-846.

Elliot, J.M. 2000. Pools as refugia for brown trout during two summer droughts: trout responses to thermal and oxygen stress. Journal of Fish Biology 56:938-948.

Ensign, W.E., Strange, R.J., and Moore, S.E. 1990. Summer food limitations reduces brook and rainbow trout biomass in a southern Appalachian stream. Transactions of the American Fisheries Society 119: 894-901.

Fausch, K.D., C.L. Hawkes, and M.G. Parsons. 1988. Models that predict standing crop of stream fish from habitat variables: 1950-1985. General Technical Report PNW-GTR-213. U.S. Department of Agriculture. Forest Service, Pacific Northwest Research Station, Portland Oregon.

Fausch, K.D. 1984. Profitable stream positions for salmonids: related specific growth rate to net energy gain. Canadian Journal of Zoology. 62: 441-451.

Fausch, K.D., and R.J. White. 1981. Competition between brook trout (Salvelinus fontinalis) and brown trout (Salmo trutta) for positions in a Michigan stream. Canadian Journal of Fisheries and Aquatic Sciences 38:1220-1227.

Flebbe, P. A. and, C. A. Dolloff. 1995. Trout use of woody debris and habitat in Appalachian wilderness streams of North Carolina. North American Journal of Fisheries Management 15:579-590. 
Fry, F.E.J., J.S. Hart, and K.F. Walker. 1946. Lethal temperature relations for a sample of young speckled trout (Salvelinus fanotinalis). University of Toronto Studies, Biological Series 54. (Publication of the Ontario Fisheries Research Laboratory 66:9-35.)

Gagen, C. J., Sharpe, W. E., and Carline, R. F. 1994. Downstream movement and mortality of brook trout (Salvelinus fontinalis) exposed to acidic episodes in streams. Canadian Journal of Fisheries and Aquatic Sciences 51: 1620-1628.

Gerking, S.D. 1959. The restricted movement of fish populations. Biol. Rev. Camb. Philos. Soc. 34:221-242.

Gippel, C. J. 1995. Environmental hydraulics of large woody debris in streams and rivers. Journal of Environmental Engineering 121: 388-395.

Golladay, S. W. and Webster, J. R. 1988. Effects of clear-cut logging on wood breakdown in Appalachian Mountain streams. American Midland Naturalist 119: 143-155.

Gowan, C. and Fausch, K. D. 1996. Mobile brook trout in two high-elevation Colorado streams: re-evaluation of the concept of restricted movement. Canadian Journal of Fisheries and Aquatic Sciences 53: 1370-1381.

Gradall, K.S., W.A. Swenson. 1982. Responses of brook trout and creek chubs to turbidity. Transactions of the American Fisheries Society 111:392-395.

Gregory, R.S. 1993. Effect of turbidity on the predator avoidance behavior of juvenile Chinook salmon (Concorhyncus tshawytscha) Canadian Journal of Fisheries and Aquatic Sciences 50:245-246.

Haines, T.A. 1981. Acid precipitation and its consequences for aquatic ecosystems: a review. Transactions of the American Fisheries Society 110:669-707.

Hairston-Strang, A.B. and P. W. Williams. 1998. Potential large woody debris sources in riparian buffers after harvesting in Oregon, U.S.A. Forest Ecology and Management. 112: 67-77.

Hakala, J. P. 2000. Factors influencing brook trout (Salvelinus fontinalis) abundance in forested headwater streams with emphasis on fine sediment. West Virginia University, Morgantown, WV.

Hankin, D.G., and G.H. Reeves. 1988. Estimating total fish abundance and total habitat area in small streams based on visual estimation methods. Canadian Journal of Fisheries and Aquatic Sciences 45:834-844.

Hart, L.G. and Summerfelt, R.C. 1975. Surgical procedures for implanting ultrasonic transmitters into flathead catfish (Pylodictis olivaris). Transactions of the American Fisheries Society 104: 56-59.

Hartman, G.F., J.C. Scrivener, and M.J. Miles. 1996. Impacts of logging in Carnation Creek, a 
high-energy coastal stream in British Columbia, and their implication for restoring fish habitat. Canadian Journal of Fisheries and Aquatic Sciences. 53: 237-251.

Harvey, B.C. 1998. Influence of large woody debris on retention, immigration, and growth of coastal cutthroat trout (Oncorhynchus clarki clarki) in stream pools. Canadian Journal of Fisheries and Aquatic Sciences 55(8):1902-1908.

Hawkins, C.P., M.L. Murphy, N.H. Anderson, and M.A. Wilzbach. 1983. Density of fish and salamanders in relation to riparian canopy and physical habitat in streams of the northwestern United States. Canadian Journal of Fisheries and Aquatic Sciences 40:1173-1185.

Heifetz, J., M.L. Murphy, and K.V. Koski. 1986. Effects of logging on winter habitat of juvenile salmonids in Alaskan streams. North American Journal of Fisheries Management 6:5258.

Hilderbrand, R. H., Lemly, A. D., Dolloff, C. A., and Harpster, K. L. 1997. Effects of large woody debris placement on stream channels and benthic macroinvertebrates. Canadian Journal of Fisheries and Aquatic Sciences 54: 931-939.

Hillman, T.W., J.S. Griffith, and W.S. Platts. 1987. Summer and winter habitat selection by juvenile chinook salmon in a highly sedimented Idaho stream. Transactions of the American Fisheries Society 116:185-195.

Hughes, N. F. 1998. A model of habitat selection by drift-feeding stream salmonids at different scales. Ecology 79:281-294.

Jordahl, D.M., and A. Benson. 1987. Effect of low pH on survival of brook trout embryos and yolk-sac larvae in West Virginia streams. Transactions of the American Fisheries Society 116:807-816.

Krueger, C.C., and T.F. Waters. 1983. Annual production of macroinvertebrates in three streams of different water quality. Ecology 64(4):840-850.

Lacroix, G.L. 1992. Mitigation of low stream pH and its effects on salmonids. Environmental Pollution 78:157-164.

Lamothe, P.J. 2002. Spatial population dynamics of brook trout (Salvelinus fontinalis) in a central Appalachian watershed. West Virginia University, Morgantown, WV.

Larson, G.L., and S.E. Moore. 1985. Encroachment of exotic rainbow trout into stream populations of native brook trout in the southern Appalachian mountains. Transactions of the American Fisheries Society 114:195-203.

Leopold, L.B. 1994. A view of the river. Harvard University Press, Cambridge, Massachusetts, $298 \mathrm{p}$. 
Lohr, S. C., and J. L. West. 1992. Microhabitat selection by brook and rainbow trout in a southern Appalachian stream. Transactions of the American Fisheries Society 121:729736.

Maret, T.R., T.A. Burton, G.W. Harvey, and W.H. Clark. 1993. Field testing of new monitoring protocols to asses brown trout spawning habitat in an Idaho stream. North American Journal of Fisheries Management 13:567-580.

Matthews, K. R. 1996. Habitat selection and movement patterns of California golden trout in degraded and recovering stream sections in the Golden Trout Wilderness, California. North American Journal of Fisheries Management 16:579-590.

Meehan, W.R. 1994. Introduction and overview. Pages 1-16, IN Influences of Forest and Rangeland Management on Salmonid Fishes and Their Habitats. W.R. Meehan, Ed. American Fisheries Society, Bethesda, MD.

Menendez, R., J.L. Clayton, P.E. Zurbach. 1996. Chemical and fishery response to mitigative liming of an acidic stream, Dogway Fork, West Virginia. Restoration Ecology. 4: 220-233.

Miner, J.G., R.A. Stein. 1996. Detection of predators and habitat choice by small bluegills: effects of turbidity and alternative prey. Transactions of the American Fisheries Society 125:97-103.

Petty, J.T., J. Freund, P.J. Lamothe \& P.M. Mazik. 2001. Quantifying the microhabitat characteristics of hydraulic channel units in the upper Shavers Fork basin. Proceedings of the Southeastern Association of Fish and Wildlife Agencies In Press

Phillips, R.W., R.L. Lantz, E.W. Claire, and J.R. Moring. 1975. Some effects of gravel mixtures on emergence of coho salmon and steelhead trout fry. Transactions of the American Fisheries Society 104:461-466.

Reeves, G.H., J.O. Hall, T.D. Roelofs, T.L. Hickman, C.O. Baker. 1991. Rehabilitating and modifying stream habitats. American Fisheries Society Special Publication 19:519-557.

Rosenfeld, J. S. and Boss, S. 2001. Fitness consequences of habitat use for juvenile cutthroat trout: energetic costs and benefits in pools and riffles. Canadian Journal of Fisheries and Aquatic Sciences 58: 585-593.

Rosenfeld, J., Porter, M., and Parkinson, E. 2000. Habitat factors affecting the abundace and distribution of juvenile cutthroat trout (Oncorhynchus clarki) and coho salmon (Oncorhynchus kisutch). Canadian Journal of Fisheries and Aquatic Sciences 57: 766774.

Rose, G.A. 1986. Growth decline in sub-yearling brook trout (Salvelinus fontinalis) after 
emergence of rainbow trout (Salmo gairdneri). Canadian Journal of Fisheries and Aquatic Science 43:187-193.

Scarnecchia, D.L. and E.P. Bergersen. 1987. Trout production and standing crop in Colorado's small streams, as related to environmental features. North American Journal of Fisheries Management 7:315-330.

Schlosser, I.J. 1995. Critical landscape attributes that influence fish population dynamics in headwater streams. Hydrobiologia 303:71-81.

Sharp, W.E., D.R. DeWalle, R.T. Leibfried, R.S. Dinicola, W.G. Kimmel, and L.S. Sherwin. 1984. Cause of acidification of four streams on Laurel Hill in Southwestern Pennsylvania. Journal of Environmental Quality 13:619-631.

Silver, S.J., C.E. Warren, and P. Doudoroff. 1963. Dissolved oxygen requirements of developing steelhead trout and chinook salmon embryos at different water velocities. Transactions of the American Fisheries Society 92:327-343.

Simonson, T.D., J. Lyons, and P.D. Kanel. 1994. Quantifying fish habitat in streams: transect spacing, sample size, and a proposed framework. North American Journal of Fisheries Management 14:607-615.

Sowden, T.K., and G. Power. 1985. Prediction of rainbow trout embryo survival in relation to groundwater seepage and particle size of spawning substrates. Transactions of the American Fisheries Society 114:804-812.

Swift, L.W., Jr. and J.B. Messer. 1971. Forest cuttings raise temperature of small streams in Southern Appalachian. Journal of Soil and Water Conservation 26:111-116.

Thompson, P. D. and Rahel, F. J. 1998. Evaluation of artificial barriers in small Rocky Mountain streams for preventing the upstream movement of brook trout. North American Journal of Fisheries Management 18:206-210.

USEPA. 1996. National Water Quality Inventory: 1996 Report to Congress. U.S. Environmental Protection Agency, Washington, DC.

Winker, K., J.H. Rappole, and M.A. Ramos. 1995. The use of movement data as an assay of habitat quality. Oecologia.101: 211-216.

Winter, J.D. 1983. Underwater Biotelemety. Pages 371-396 in B.R. Murphy and D.W. Willis, editors. Fisheries techniques. American Fisheries Society, Bethesda Maryland.

Witzel, L.D. and H.R. MacCrimmon. 1981. Role of gravel substrate on ova survival and alevin emergence of rainbow trout, Salmo gairdneri. Canadian Journal of Zoology 59:629-636.

Wohl, N.E. and R.F. Carline. 1996. Relations among riparian grazing, sediment loads, 
macroinvertebrate, and fishes in three central Pennsylvania streams. Canadian Journal of Fisheries and Aquatic Sciences 53(suppl. 1):260-266.

Young, M.K.1996. Summer movements and habitat use by Colorado River cutthroat trout (Oncorhynchus clarki pleuriticus) in small, montane streams. Canadian Journal of Fisheries and Aquatic Sciences 53: 1403-1408.

Young, M. K. 1995. Telemetry-determined diurnal positions of brown trout (Salmo trutta) in two south-central Wyoming streams. American Midland Naturalists 133:264-273. 


\section{Chapter 2:}

\section{Abstract}

Brook trout (Salvelinus fontinalis) in Appalachian headwater streams experience large fluctuations in stream discharge that may affect habitat use and movement patterns. To evaluate the influence of different flow regimes upon habitat use, home range, and movement patterns of brook trout in Appalachian headwater streams I implanted brook trout with radio tags and tracked their movement for approximately 30 days during late spring 2002 and early spring 2003. The hypotheses tested were 1) There is no difference between habitat used by brook trout and available habitat: 2) High flow events have no affect on brook trout habitat selection or movement: 3) Spatial structure of preferred habitat does not influence movement. The results of my research showed that brook trout used pools as their primary habitat and that large woody debris was used as cover and as a pool forming structure more than what can be expected by chance. Other habitat variable use such as water depth and velocity were artifacts of pool use. Results also showed that the majority of the brook trout in the study were very mobile, moving hundreds of meters in one day. These results are very similar to other telemetry studies with trout. Due to the results showing high levels of brook trout movement, it is suggested that population and habitat analysis should be conducted on a large spatial scale. The results also reaffirm the importance of pools and LWD to brook trout habitat. Thus, management implications should include pool preservation and riparian zone protection to increase the potential of LWD in the stream. 


\section{Introduction:}

Brook trout (Salvelinus fontinalis) are the only salmonid native to the Appalachians and are a very popular game fish in West Virginia. They can be found in many Appalachian headwater streams, but they have been losing habitat since logging and mining began to spread through the state in the early 1900's. Headwater streams are important to brook trout for many reasons, including water quality, spawning, food availability and suitable habitat. Cold water temperature is the water quality found in these headwater streams that tend to make the environment unique for brook trout. Spawning requires the appropriate sized substrate (Benson 1953, Curry et. al 1995). Hakala and Hartman (in review) suggests that spawning substrate ranges from 4-30 mm. Food is mostly a mixture of terrestrial insects and aquatic insect larva (Wipfli 1997, Kawaguchi and Nakano 2001, Sweka 2003). The relatively closed canopy of headwater streams not only offers opportunity for terrestrial insects to fall in the stream, but also adds leaf litter that supports aquatic invertebrate shredders. Appalachian headwater streams, are characterized by steep slopes with generally large cobbles and boulders (Rosgen 1994, Montgomery and Buffington 1997). Large substrate in the stream offers good habitat for hiding and resting brook trout. The wooded riparian zone of head water streams also provides large woody debris (LWD), which provides habitat as well.

The most widely used type of primary habitat for brook trout are pools (Flebbe and Dollof 1995, Young 1995, Berg et al. 1998, Bunnell et al. 1998). There are several different kinds of pools including dammed pools, plunge pools, backwater pools, lateral scour pools, straight scour pools, step pools and trench pools. They differ mostly in how they were formed. Some are formed by the act of erosion around structures such as boulders, rootwads, and LWD (Bozek and Rahel 1991), while some are considered free form meaning there is no structure 
associated with their formation. Although pools are important to brook trout on a daily basis, they become even more important during droughts and floods.

A study done by Elliott (2000) investigated the importance of pools during summer droughts. He had found that brown trout (Salmo trutta) were forced into pools by the lack of water, which also prevented migration. Hakala and Hartman (in press) found that the relationship between pool area and brook trout densities were age dependent and very critical during drought. Therefore evidence shows that adult carrying capacity is limited during droughts by available pool area (Elliott 1987, Lestelle et al. 1993, Hakala and Hartman in press). Reeves et al. (1991) reviewed studies on habitat rehabilitation where fish became more abundant due to an increase in the number, size and depth of pools, especially in drought stricken streams. Floods (high flows) resulting in the increase of discharge and velocity, cause fish to seek refuge within pools (Cederholm et al. 1997, Bisson et al. 1987, Elliott 2000, Rosenfeld and Boss 2001, Bozek and Rahel 1991). Floods tend to be most devastating to brook trout populations when associated with debris flows (Carline and McCullough 2003). Although floods have been shown to be detrimental to brook trout populations, and pools are known to be important to other salmonids during high flow, habitat use of brook trout has not been quantified during spring high flows.

The objective of this study is to evaluate brook trout habitat use, home range, and movement patterns in an Appalachian headwater stream during spring and high flow events. To do so I have implanted brook trout with radio tags and tracked their movement for approximately 30 days during late spring 2002 and early spring 2003. The hypotheses being tested are 1) There is no difference between habitat used by brook trout and available habitat: 2) High flow events have no affect on brook trout habitat selection or movement: 3) Spatial structure of preferred habitat does not influence movement. 


\section{Study Area:}

This study was conducted on Birch Fork, a tributary of the Middle Fork River, Randolph County West Virginia (Figure 1). Birch Fork has a stream length of $5.6 \mathrm{~km}$ and is located on property owned by MeadWestvaco, Inc. The stream runs through a portion of the Allegheny Mountains with well drained acidic soils. The upper portion of the stream is limed every year by the West Virginia Department of Natural Resources (DNR). Precipitation in this area often reaches more than $130 \mathrm{~cm}$ a year. The immediate watershed has numerous skid trails and abandoned haul roads. A road leading to a gas well allows the lower 1,000 meters to be easily accessible to vehicles and therefore local fishermen. A logging road crosses Birch Fork 4,000 meters above its mouth. The road is located, along with most of Birch Fork, on the Westvaco Wildlife and Ecosystem Research Forest (WWERF) and therefore is not open to public use. The area surrounding Birch Fork is dominated by mid- to high-elevation deciduous forest communities. Two clear cuts are located within the Birch Fork drainage, approximately 300-500 meters from the stream. One was in the process of being cut during the study.

This study stream was chosen because it has a locally high brook trout population and because habitat manipulation was conducted on this stream in August 2000. The manipulation was in the form of added LWD. Large woody debris is known to be a pool-forming mechanism (Harvey 1998, Rosenfeld et al. 2000, Angermeier and Karr 1984, Bozek and Rahel 1991). These additions cover approximately $20 \%$ of the total stream length, thus, there are relatively large areas of varying habitat complexity along the stream gradient. 


\section{Methods:}

The first season of the study began on May 4, 2002 and lasted through June 21, 2002. The second season began on March 27, 2003 and ended May 8, 2003. Before implanting and releasing the fish, I obtained total pool area along the entire study stream. I also marked the stream off in 25 meter increments. This was necessary as pool area measurements were used to determine sections of the stream containing $5 \%$ of the total pool area for fish placement. Pool areas were measured by using the basinwide visual estimation technique (BVET) as in Dolloff et al. (1997). In the first season the BVET survey began 200 meters above the point where Birch Fork meets Rocky Run (Figure 1). Since Rocky Run was not included in the study, the lower 200 meters were used as a buffer to minimize the likelihood of fish moving out of the study area. For the second season, the pool area measurements did not begin until the 1,000 meter mark above Rocky Run in an effort to negate angling losses from the lower reach.

Available habitat was assessed as in Petty et al. (2002), by breaking the Birch Fork site into 3 regions (upstream, midstream, and downstream). The downstream region was marked off from the intersection of Rocky Run up to the intersection of Sugar Drain (approximately 2.4$\mathrm{km})$. The upstream region consisted of $1.2 \mathrm{~km}$ of manipulated stream habitat in the form of added LWD. The midstream therefore consisted of the remaining 3.6-km stretch between Sugar Drain and the manipulated site. Habitat measurements were taken within portions defined by the Representative Reach Extrapolation Technique (Platts et al. 1983). Two reaches, measuring 35 times the mean stream width, were randomly selected within each region. Transects within these reaches were spaced 2-3 times the mean stream width. Microhabitat usage variables were measured at 5 equally spaced points across each transect. 
The microhabitat variables measured included: primary habitat type (pool, riffle, run), structural association (LWD, boulders, root wads, etc.), distance to nearest bank, distance to and type of cover, \% canopy cover, water depth, water temperature, and current velocity. During the second season (2003), \% canopy cover was not recorded due to seasonal variation during the course of radio tracking, and water temperature was not taken because it remained within the brook trout preference zone and proved to be excess data. Percent substrate composition, visually estimated within a $400 \mathrm{~cm}^{2}$ quadrat (Petty et al. 2002), was also measured using modified Wentworth classification for substrate particle sizes (McMahon et al. 1996). Large woody debris was defined as any piece of wood within the bankfull channel, bigger than $10 \mathrm{~cm}$ in diameter and $1 \mathrm{~m}$ in length (Overton et al. 1997). Boulders were defined as greater than $30 \mathrm{~cm}$ along the median axis (Young 1996). Average velocity was considered the velocity at $60 \%$ of the water depth (Petty et al. 2002). Distance to nearest bank and nearest cover was measured using a tape measurer. Water depth was measured using a calibrated, flat bottom wading rod (Orth 1983). Cover type, habitat type and structural associations were all visually classified by the same researcher to minimize variability.

On days tracking occurred, discharge measurements were taken at three different points along Birch Fork. Discharge was taken at stations within the stream at the down reach (meter 1260), the mid reach (meter 2860) and the upper reach (meter 4375) to record discharge variations. A flow meter was used to record the flow at $60 \%$ depth at 10 equidistant points along the cross section of the stream. Wetted width and the depth at each point were also measured and used to calculate discharge. This data was later used to determine high flow events.

Radio telemetry was used to monitor daily and diel movement of 20 brook trout and their habitat use during each of two sample periods (May-June 2002, March-May 2003). The fish used 
for the telemetry study were collected from streams neighboring the Birch Fork study stream. Fish from Birch Fork were not used for two reasons. First of all, the fish needed to be relatively large for the study in order to carry the tag. Obtaining 20 fish of this size from one stream would be difficult and it could also disturb that stream's population dynamics, which involved the study of the LWD manipulation for an allied study (Sweka 2003). The second reason is that obtaining fish from other streams allowed a more random placement of fish, and reduced the likelihood of “homing” by brook trout, which could bias movement results.

Brook trout were obtained by means of a DC pulsed electrofisher and weighed before being selected for the study. Each fish needed to weigh at least 65 grams to carry the 1.3-gram tag. The tag should not exceed 2\% of the fish’s total weight (Winter 1983, Bunnel et al. 1998). The fish were transported to Birch Fork in 5 gallon buckets. Surgery and release took place within 1-12 hours of capture.

At three points along Birch Fork 20 brook trout were surgically implanted with radio transmitters and released. Surgeries were performed similar to Hart and Summerfelt (1975) and Young (1995). The fish were anesthetized using a $120 \mathrm{mg} / \mathrm{l}$ clove oil solution (Anderson et al. 1997) for approximately 3-4 minutes or until they lost equilibrium. Their lengths and weights were then measured. Radio tags were inserted through an incision approximately $8 \mathrm{~mm}$ long, located immediately anterior to the pelvic girdle and about $3 \mathrm{~mm}$ right of the ventral midline (Young 1995). Three sutures, approximately $3 \mathrm{~mm}$ apart, were used to close the incision (Hart and Summerfelt 1975). Surgery time was kept under 3 minutes to increase survivorship (Jeffrey Isely, Clemson University, personal communication).

The radio tags (F1400 series, Advanced Telemetry Systems) were sealed in epoxy and weighed 1.3 grams with external dimensions of 8x16x7 mm. The tags were set to pulse at 35 
ppm, giving them a warranty battery life of 28 days and battery capacity of up to 56 days. Each tag had a unique frequency which permitted identification of individual fish.

Following surgical procedures, fish were given 10 -15 minutes to recover, while being transported to their designated stream section. There were 20 sections, each containing $5 \%$ of the total pool area and each received one randomly selected, implanted fish. This was done so that the fish were stocked at an equivalent density in relation to pool area, and in hopes of using the length of each section as an index of habitat quality. Personnel relocating the fish located appropriate sections by using 25 meter markers posted on flagging along the length of Birch Fork. Fish were placed in the nearest pool within the designated section (for recovery purposes) and observed to verify recovery from the anesthesia. The fish were given at least 1-2 days to resume normal behavior before tracking began.

Tracking was conducted by walking parallel to the stream, within $50 \mathrm{~m}$ (Young 1995). Signals were reported to be detected from approximately 100 m away (Matthews 1996), but we actually found them to be detectable at 200 meters. Triangulation was used to determine the location of the trout. Visual affirmation was also attempted to ensure more accurate locations. For compatibility, the telemetry equipment (the transmitters, hand held loop antenna, and scanning receiver) were bought from the same manufacturer (Young 1995).

Each fish was located once a day. At the point of each located fish, the same microhabitat measurements taken for available habitat were taken for habitat use. In addition, during the 2002 study several randomly selected fish were tracked hourly during a 24-hour period (Young et al. 1997). This was to observe diel movements, which may differ from day to day movements (Bunnel et al. 1998). The observer did not disturb the fish or enter the stream during this 24-hour tracking period. All forms of tracking continued until battery life of the majority of the 
transmitters failed (approximately 28-56 days). For the first season of tracking all tags were still transmitting after 35 days, excluding the tags lost to angling. During the second season, all 20 fish were still transmitting after 40 days.

Brook trout movement and locations were determined by measuring the distance to the closest 25-meter mark on a line parallel to the thalweg (Young 1995). Total movement by each fish was calculated in three categories: home range, net movement and cumulative movement over time. Home range was measured as the distance between the furthest upstream and downstream locations (Young 1997). Net movement was measured by taking the difference from the original release location to the final location of the study. Cumulative movement was a sum of all movements from day to day and more importantly hour to hour for the fish monitored during the 24-hour period. We felt the length of each release segment (5\% pool area) can be considered an index of habitat quality, using distance between preferred pool habitat units, with longer segments corresponding to lower pool:riffle ratios and therefore poorer habitat quality. Release unit length would appear to be a good measure of habitat quality given that Sweka (2003) found such habitat complexity was significantly related to brook trout density in this, and other nearby streams. Cumulative movement and home ranges were then correlated to the length of the segment of release for each fish. Microhabitat preferences were determined by using the log-likelihood ratio test for discrete variables (primary habitat type and structural association) and the Mann-Whitney test for continuous variables (distance to nearest bank, water depth, and velocity). In all tests, alpha was set at 0.05 .

Comparisons of habitat use versus availability were calculated with three different data sets. The first data set uses all the locations for each fish without duplicates (data set 1). Duplicates were defined as any location a fish was found in more than once. These locations are 
not considered independent of each other. The next step to ensure independent samples, was to use the same number of locations for each fish (data set 2). Some fish had twice as many locations as others, and to prevent over emphasis on these individuals' preferences, locations were randomly deleted until all fish had 9 locations for the first season and 8 for the second season (Rogers 1998). The final, most extreme step was to only consider one randomly selected location from each fish (data set 3). The argument here is that samples from the same fish can not truly be independent of each other (Aebischer et al. 1993), and that in a telemetry study the experimental units are the individual fish not individual locations (Aebischer et al. 1993, Winter 1996, Otis and White 1999), hence, only one random observation on habitat use should be used. During the second season (spring 2003), fish habitat use during high flow events were compared to habitat use during non-high flow events. High flow events were determined by graphing the discharge for each day of tracking (Figure 2). The cut-off for high flow events was determined by using the $75^{\text {th }}$ percentile which resulted in the any discharge greater than 0.35 $\mathrm{m}^{3} / \mathrm{s}$.

\section{Results:}

$\underline{\text { Movement }}$

Of the 20 fish tagged during the first experiment, four were lost and presumed eaten. Thus, with a sample size of 16 for the first season, each fish was located an average of 17 (range 10-21) times and occupied an average of 15 unique locations (range 9-20) (Table 1). For the first season of tracking the average home range was 569 meters ( $\mathrm{n}=16$, range 87-2681 m) (Figure 3), the average cumulative distance traveled by each fish during the period was 1136 meters $(n=16$, range 274-4469 m) (Figure 4) and net movement averaged 337.4 meters in the upstream 
direction ( $n=16$, range $-1195-+5 m$ ) from where they were released to where they were last located (Table 1, Figure 8).

With a sample size of 20 for the second season, each fish was located an average of 19 times (range 15-20) with an average of 14 unique locations (range 8-18) (Table 2). For the second season of tracking the average home range was 313 meters ( $n=19$, range 4-1395 m), the average cumulative distance was 777 meters $(\mathrm{n}=20,8.5-2996 \mathrm{~m})$, and the average net movement was 27.0 meters in the down stream direction ( $\mathrm{n}=20$, range $-518-+382 \mathrm{~m})$ (Table 2, Figure 8).

\section{Spring 2002 Habitat Use}

In the first season of tracking (late spring), there were significant differences in available primary habitat and all three use data sets (Table 3, Figure 5, Figure 6, Figure 7). Brook trout used pools more than what was available. There was only a significant difference in pool formation structure for data set $1(\mathrm{n}=262)$, which showed pools formed by LWD were being used more in proportion to availability, and no difference for data set $2(n=142)$ or data set 3 $(\mathrm{n}=19)$ (Table 3). Cover type use was significantly different for data sets 1 and 2, but not for data set 3. Data sets 1 and 2 showed use of rootwads more than in proportion to availability. Substrate was significantly different for data sets 2 and 3 but not 1 (Table 3). Data sets 2 and 3 suggest that habitat with bedrock as a substrate was used more than what was available. All continuous variables (velocity, depth, distance to bank, distance to cover and percent canopy) were significantly different in all three data sets except for velocity in data set 3 (Table 3). The differences showed that the fish were found in faster, deeper water, areas further from the bank and closer to cover than what was measured as available (Table 3). 


\section{Diel Tracking}

The 24-hour tracking period was conducted on a randomly selected group of three fish on June $18^{\text {th }}$ and $19^{\text {th }}$. The average cumulative movement for all three fish was 40.8 meters. Of their cumulative movement, 85\% occurred during the hours of 0530-0930 h and 1730-2130 h. During this time they were found in runs and riffles. No further diel data was collected due to the time requirement.

\section{Spring 2003 Habitat Use}

In the second season of tracking (early spring 2003), there were significant differences in both primary habitat and pool formation structure for all three data sets (Table 4, Figure 5, Figure 6, Figure 7). Pools formed by LWD were used by brook trout more than in proportion to availability of other primary habitat and other pool forming mechanisms. There was a significant difference in cover type for data set $1(n=242)$ and data set $2(n=152)$ but not $3(n=20)$ (Table 4). Data sets 1 and 2 showed brook trout used LWD and rootwads more than what can be expected by availability. Substrate was not significantly different in any of the data sets (Table 4). The results for the continuous variables were the same as the first season. When compared, all variables were significantly different in all data sets except for velocity in the third data set (Table 4). The differences showed that the fish selected slower velocity, deeper water, a distance further from the bank, and a distance closer to cover than what was available (Table 4).

\section{High Flow Habitat Use}

During spring 2003 tracking, fish habitat use within high flow events ( $>0.35 \mathrm{~m}^{3} / \mathrm{s}$ ) were compared to habitat use during non-high flow events. The results for continuous variables 
showed that the fish selected significantly slower velocity, deeper water, further positions from the bank and further positions from cover during high flow events than non-high flow events (Table 5). The results for discrete variables showed that the trout habitat selections were significantly different for primary habitat, structure, and type of cover. There was no significant difference between high flow events and non-high flow events for substrate (Table 5).

\section{Discussion:}

The first season of tracking was very much a learning process, resulting in a number of changes from the first season to the second season. First of all, the study area on Birch Fork was changed in an effort to decrease the fishing pressure on the tagged brook trout. The lower end of the site was moved 1,000 meters up stream away from a public accessible road. Several fishermen and/or their vehicles were seen on this lower kilometer of stream. This move also reduced the chances of fish leaving Birch Fork and moving into Rocky Run, the stream where most of the fish were collected prior to implantation.

We also had a problem in the first season when the available habitat was measured. The use and available habitat data suggested that the brook trout were occupying positions of higher velocity than what was considered available. This was not expected considering brook trout tend to select slower velocity positions usually next to high velocity for feeding (Baker and Coon 1997). Examination of discharge data collected throughout the study indicated available habitat measurements were measured on the days with the lowest discharge. This caused the available data to inaccurately assume slower velocity than what was really available.

Canopy cover and water temperature were not measured in the second season. Canopy was not included because of natural seasonal variation from the beginning of the study and the 
end, especially for the spring tracking. Temperature was taken in the first study, but did not prove to be an issue for the brook trout. The temperature ranged from $8^{\circ} \mathrm{C}$ to $17^{\circ} \mathrm{C}$, which is well within the suitable temperature range for salmonids (Meisner 1990, MacCrimmon and Campbell 1969, Fry 1949). Cutting out percent canopy and water temperature not only eliminated extra data, it also saved time in the field.

Brook trout exhibited different scales of movement among individuals with some remaining near the release pool and others moving several kilometers during tracking. There seemed to be quite a difference in the distances covered between late spring and early spring tracking seasons. The first season (late spring) had a home range of 637 meters compared to the second seasons (early spring) 301 meters. There was an even larger difference between the cumulative movement being 1,136 meters for the first season and 777 meters for the second, a difference of 359 meters. The net movement showed that in general the fish in the first season moved quiet distance (337 m) up stream, where as the fish in the second season moved a short distance (27 $\mathrm{m}$ ) down stream. This is most likely to the increased discharge in the second season or simply due to the fact that the study site was moved 1,000 meters up stream for the second season.

The results for cumulative movement and home range may show that the brook trout are more active during the late spring than the early spring. This may have to do with the water being colder in the early spring. It may also have to do with the fact that the brook trout were more content where they were during the second season than the first, or the higher flows in the early spring restricted their movement. The first season had an average of 17 relocations and 15 unique locations for each fish, whereas the second season had an average of 19 relocations and 14 unique locations. So, even though the second season had more locations in general on each 
fish, they seemed to be staying in the same spot more often. In the second season of tracking, fish \#744 and \#891 never left the original pools they were placed. Both were spotted several times as they moved within the pools. Both pools were quite large $124 \mathrm{~m}^{2}$ and $73 \mathrm{~m}^{2}$ respectively and both had large boulders. One of the pools also had a fawn carcass dangling from some LWD.

Both seasons suggest that brook trout in headwater streams are quite mobile, which opposes the thought of restricted movement by salmonids (100 m home range) (Gerking 1959, Matthews 1996). Young (1995), Harvey (1998), and Gowan and Fausch (1996) also found large amounts of movement by trout. Young (1996) found cutthroat trout in small montane streams from May to August had a median home range of 233m (range, 0-1792 m) and a median total movement was $332 \mathrm{~m}$ (range, 0-2443m). There were even a couple of large debris dams that several fish were able to move up and down stream through. Such movement may prove to be important for biologists to consider when studying trout population structure and management procedures. Analysis of habitat and populations should be covered over a large spatial scale (Gowan et al. 1994, Harvey 1998).

Some fish were left out of the analysis many several different reasons. Two were confirmed catches by local fishermen and two others were suspected catches. All four were last located in the lower kilometer of Birch Fork. One fish left the study sight very early in the study. Another one was located in a culvert $80 \%$ of the time and habitat measurements were unable to be taken. One of the tags in the first season was tracked to a location in the woods approximately 200 meters from the stream. There was only one tag expulsion (fish \#241) during the tracking period occurring 2.5 weeks into the first season of the study when the tag was located in the stream during routine tracking. 
Fish \#844, \#911 and \#451 were each suspected dead at one point during the study. Fish \#911 had a complicated surgery with difficulty in suturing. That fish was located under a root wad several days in a row. Suspecting it may have died or expelled the tag I entered the stream where I could see the trailing antenna. Upon grabbing the antenna it was determined that the fish was still alive. The fish swam away but returned the next day to the same root wad. Fish \#451 was located under a boulder for several days and therefore suspected dead, but was later located approximately 50 meters up stream. Fish \#844 was also located under a boulder for several days, but was never located elsewhere before the study came to an end. All three of these fish were included in the data analysis.

For the purpose of clarity, I will only discuss the habitat results from data set 2 from the second season of tracking (2003). Data set 2 includes an equal number of locations from each fish. Data set 1 included all locations from each fish, excluding duplicates. This left too much emphasis on the habitat use of fish with twice as many locations as others. Data 3 simply excluded too much valuable data. It also caused the price of a tag to be quite excessive for only one observation. The results from the second season were used because the first season was very a much a learning experience and they both had very similar results (Tables 3 and 4).

As was expected from reviewed literature (Flebbe and Dollof 1995, Young 1995, Berg et al. 1998, Bunnell et al. 1998), both seasons showed clearly that brook trout selected pool habitats over riffles and runs more than what could be expected by chance. The second season showed an even higher percentage of pool use (55\%) by the brook trout than the first season (45\%). This is most likely due to the overall higher discharge during early spring than in late spring (Figure 2). Increases in discharge and velocity, causes fish to seek refuge within pools (Cederholm et al. 1997, Bisson et al. 1987, Rosenfeld and Boss 2001, Bozek and Rahel 1991). It has also been 
shown that pools are very important in drought conditions (Elliott 2000) and as winter refuge (Chisholm and Hubert 1987).

Brook trout were also found in habitats with decreased velocity and increased depth than what could be expected by chance. This is most likely due to the relationship these variables have with the frequent use of pools. The reasons salmonids use pools as primary habitat appears related to the availability of slower and deeper water in these habitats. Heggenes et al. (1991) found very similar results in his study on cutthroat trout. Young's (1995) study with brown trout found there to be no difference in mean water velocity between used and available habitat, but did find they used deeper water. He accounted this to the brown trout possibly being more concerned with feeding than an energetically favorable position.

The current study observed that brook trout were closer to cover and further from the bank than what can be expected by chance. Young (1995), Young (1996) and Heggenes et al. (1991) all found a salmonid preference closer to cover. This is most likely linked to predator avoidance and/or foraging. The shade from cover may allow the brook trout to ambush their prey more effectively (Helfman 1981) and it may also provide hiding from mammalian predators (Young 1995). Young (1995) and Heggenes et al (1991) found trout closer to the bank rather than further from the bank as in this study and as in Young (1996). The differences between trout locations in reference to the bank may have to do with the wetted width of the study streams. Studies on smaller, narrower streams (2.6-5.0 m) showed trout to occupy positions further from the bank (Young 1996, current study). Whereas, studies conducted on larger, wider streams (>10 m) showed trout used habitat closer to the bank (Young 1995, Heggenes et al. 1991). Lohr and West (1992) found that brook trout moved to more midstream positions after rainbow trout were 
removed from competition. The stream in this study was an average of $7.3 \mathrm{~m}$ wide and falls in line with studies on smaller streams.

The results suggest that brook trout use pools formed by LWD more than would be expected based upon availability. Results also suggest brook trout use LWD and rootwads for cover more than what is available to them. Both these findings agree with Young (1995). This also supports the idea of LWD being important to brook trout habitat. Not only does LWD increase the number of pools (Hilderbrand et al. 1997), the depth of pools (Rosenfeld et al. 2000), and the complexity of pools (Harvey 1998), it also increases invertebrate production by providing habitat and accumulating organic storage (Angermeier and Karr 1984, Cederholm et al. 1997, Bisson et al. 1987). So, it was not surprising to find the brook trout so involved with the LWD within the stream.

The diel data (2002) showed that during the 24-hour period the average cumulative movement for the three fish was 40.8 meters. We also found that $85 \%$ of the total distance each fish moved occurred during the times of 0530-0930 $\mathrm{h}$ and 1730-2130 $\mathrm{h}$. During these movements, the fish were found in runs and riffles. This suggests that this is when brook trout are most active and therefore most likely to be feeding. Rousel et al. (1999) found that brown trout foraged during the day in riffles. Bunnel et al. (1998) found that in the spring brown trout moved mostly at sunrise and sunset. Several studies suggested salmonid peak feeding occurred at dusk as a response to an increase in drift and at dawn because of fish hunger (Allan 1981, Bisson 1978, Ware 1972, Elliott 1973). Although there is very little data from this study on brook trout diel movement, what was found does seem to correspond with what these other studies concluded. 
There were differences found between the habitat brook trout use during high flow events and non-high flow events (Table 5). Even though the brook trout use pools more during both events it seems they use riffles more during high flow events than during non-high flow events. Riffles are also used in higher discharge when compared to overall daily discharge measurements (Figure 9). This is the opposite of what would be expected (Cederholm et al. 1997, Bisson et al. 1987, Rosenfeld and Boss 2001, Bozek and Rahel 1991). This contradiction of other studies may be because the brook trout were finding current refuge behind boulders within the riffles and runs (Heggenes 1988, Bachman 1984), or they may have been more concerned with feeding on increased drift in riffles (Rousel et al. 1999). It could also be due to the way high flow events were defined. Statistics on the difference of habitat use between high flows and non-high flows were done on the mean values and not the frequency of distribution. This may also explain some of the contradictions.

There was not a big difference between the use of pool formations during high flows, but during non-high flows, the brook trout selected pools formed by LWD 50\% of the time. This may confirm that LWD forms deeper pools than boulders and free form do (Rosenfeld et al. 2000). Boulders were the most frequently used cover type in both events, but during non-high flows they were used 9\% more. During high flows there seemed to be more use of root wads. Root wads may offer more protection from high flows and therefore be something the brook trout seek out. Root wads only made up $2 \%$ of available cover during the second season. High flows did not alter the brook trout selection of substrate. The brook trout were found in slower, deeper water during high flow events than during non-high flow events. This may be due to the fact that they were seeking out refuge from the increased discharge. Heggenes (1988) found no difference in habitat use by brown trout due to increased flows. 
There was no evidence of fish displacement down stream during high flows $\left(>0.35 \mathrm{~m}^{3} / \mathrm{s}\right)$ in this study. This does not mean that there was no displacement. The brook trout that were tagged were large adults, and small juveniles would be much more likely to be washed down stream by high discharge. Adult brook trout generally find low velocity refuge within the bed roughness (Heggenes 1988) or near large rocks (Bachman 1984), and are able to hold their position.

We could not find enough evidence that habitat use (Figure 10) or movement (Figure 11) by individual fish were significantly affected by where they were originally placed in the stream. We were unable to find a link between the spatial structure of preferred habitat and movement. The lengths of each of the $5 \%$ pool area sections could not be used as an index of habitat quality or linked to movement (Figure 12). However it does appear that fish near the 3000 meter mark on Birch Fork where moving out of the area. They moved upstream in 2002 and down stream out 2003. This may be a reference to a lack of optimal habitat available in that section of the stream. In conclusion, habitat use by brook trout in an Appalachian headwater stream during the spring season has proven to be very similar to habitat use by other salmonids in other studies. This study has reaffirmed the importance of pools and the importance of LWD to brook trout habitat in headwater streams, especially during high flow events. Brook trout in the current study seem to be quite mobile, some moving hundreds of meters in one day. These results along with several other studies continue to question the restricted movement paradigm (Gerking 1959). The conclusions made in this study should be considered by personnel involved in population analysis, habitat improvements, and management implementations. Due to the results showing high levels of brook trout movement, population and habitat analysis should be conducted on a large spatial scale (Gowan et al. 1994, Harvey 1998). Habitat improvements should consider 
adding structures such as LWD (Sweka 2003) to create more pools, keeping in mind habitat complexity. Management practices should include pool preservation and riparian zone protection to increase the potential of LWD in the stream. 


\section{Literature Cited}

Aebischer, N.J., P.A. Robertson, and R.E. Kenward. 1993. Compositional analysis of habitat use from animal radio-tracking data. Ecology 74:1313-1325.

Allan, J.D. 1981. Determination of diet of brook trout (Salvelinus fontinalis) in a mountain stream. Canadian Journal of Fisheries and Aquatic Sciences 38:184-192.

Anderson W.G., McKinley R.S., and Colavecchia M. 1997. The use of clove oil as an anesthetic for rainbow trout and its effects on swimming performances. North American Journal of Fisheries Management 17, no.2 (1997) p. 301-307.

Angermier, P. L. and Karr, J. R. 1984. Relationships between woody debris and fish habitat in a small warmwater stream. Transactions of the American Fisheries Society 113: 716-726.

Bachman, R.A. 1984. Foraging behavior of free-ranging brown trout, Salmo trutta, in a stream. Transactions of the American Fisheries Society 113:1-32.

Baker, E. A. and Coon, T. G. 1997. Development and evaluation of alernative habiat suitability criteria for brook trout. Transactions of the American Fisheries Society 126: 65-76.

Benson, N.G. 1953. The importance of groundwater to trout populations in the Pigeon River, Michigan. Transactions of the North American Wildlife Conference 18:268-281.

Berg, N., Carlson, A., and Azuma, D. 1998. Funcition and dynamics of woody debris in stream reaches in the central Sierra Nevada California. Canadian Journal of Fisheries and Aquatic Sciences 55: 1807-1820.

Bisson, P.A., et al. 1987. Large woody debris in forested streams in the Pacific Northwest, past, present, and future; Contribution no. 57. Streamside Management, Forestry and Fishery Interactions, E.O. Salo and T.W. Cundy, eds., Coll. Of Forest Resources, University of Washington, Seattle , Washington, 143-190.

Bisson, P.A. 1978. Diel food selection by two sizes of rainbow trout (Salmo gairdneri) in an experimental stream. Journal of the Fisheries Research Board of Canada 35:971-975.

Bozek, M.A. and F.J. Rahel. 1991. Assessing habitat requirements of young Colorado River cutthroat trout by use of macrohabitat and microhabitat analyses. Transactions of the American Fisheries Society 120:571-581.

Bunnel, D.B.Jr., Isely, J.J., Burrel, K.H., and Van Lear, D.H. 1998. Diel movements of brown trout in a southern Appalachian river. Transactions of the American Fisheries Society 127:630-663.

Carline, R.F, B.J. McCullough. 2003. Effects of floods on brook trout populations in the 
Monongahela National Forest, West Virginia. Transactions of the American Fisheries Society 132:1014-1020.

Cederholm, C. J., Bilby, R. E., Bisson, R. E., Bumstead, T. W., Fransen, B. R., Scarlett, W. J., and Ward, J. W. 1997. Responses of coho salmon and steelhead to placement of large woody debris in a coastal Washington stream. North American Journal of Fisheries Management 17: 947-964.

Chisholm, I.M., W.A. Hubert. 1987. Winter stream conditions and use of habitat by brook trout in high-elevation Wyoming streams. Transactions of the American Fisheries Society 116:176-184.

Curry, R.A., D.L.G. Noakes and G.E. Morgan. 1995. Groundwater and the incubation and emergence of brook trout. Canadian Journal of Fisheries and Aquatic Sciences 52:1741 1749.

Dolloff, C.A., H.E. Jennings, and M.D. Owen. 1997. A comparison of basinwide and representative reach habitat survey techniques in three Southern Appalachian watersheds. North American Journal of Fisheries Management 17:339-347.

Elliot, J.M. 2000. Pools as refugia for brown trout during two summer droughts: trout responses to thermal and oxygen stress. Journal of Fish Biology 56:938-948.

Elliott, J.M. 1987. Population regulation in contrasting populations of trout Salmo trutta in two lake district streams. Journal of Animal Ecology 56:83-98.

Elliott, J.M. 1973. The food of brown and rainbow trout (Salmo trutta and S. gairdneri) in relation to the abundance of drifting invertebrates in a mountain stream. Oecologia 12:329-347.

Flebbe, P. A. and, C. A. Dolloff. 1995. Trout use of woody debris and habitat in Appalachian wilderness streams of North Carolina. North American Journal of Fisheries Management 15:579-590.

Fry, F.E.J., J.S. Hart, and K.F. Walker. 1946. Lethal temperature relations for a sample of young speckled trout (Salvelinus fanotinalis). University of Toronto Studies, Biological Series 54. (Publication of the Ontario Fisheries Research Laboratory 66:9-35.)

Gerking, S.D. 1959. The restricted movement of fish populations. Biol. Rev. Camb. Philos. Soc. 34:221-242.

Gowan, C. and Fausch, K. D. 1996. Mobile brook trout in two high-elevation Colorado streams: re-evaluation of the concept of restricted movement. Canadian Journal of Fisheries and Aquatic Sciences 53: 1370-1381.

Gowan, C., M.K. Young, K.D. Fausch, and S.C. Riley. 1994. Restricted movement in resident 
stream salmonids: a paradigm lost? Canadian Journal of Fisheries and Aquatic Science 51:2626-2637.

Hakala, J. P. and K. J. Hartman. (In review). Fine sediment sizes and levels influencing brook trout abundance in forested headwater streams. Forest Management and Ecology.

Hart, L.G. and Summerfelt, R.C. 1975. Surgical procedures for implanting ultrasonic transmitters into flathead catfish (Pylodictis olivaris). Transactions of the American Fisheries Society 104: 56-59.

Hakala, J. and K. J. Hartman. (In press). Drought affect on stream morphology and brook trout (Salvelinus fontinalis) populations in forested headwater streams. Hydrobiologia.

Harvey, B.C. 1998. Influence of large woody debris on retention, immigration, and growth of coastal cutthroat trout (Oncorhynchus clarki clarki) in stream pools. Canadian Journal of Fisheries and Aquatic Sciences 55(8):1902-1908.

Heggenes, J., T.G. Northcote, A. Peter. 1991. Seasonal habitat selection and preferences by cutthroat trout (Oncorhynchus clarki) in a small, coastal stream. Canadian Journal of Fisheries \& Aquatic Sciences 48, no.8 (1991) p. 1364-1370.

Helfman, G.S. 1981. The advantage to fishes of hovering in shade. Copeia 1981:392-400.

Hilderbrand, R. H., Lemly, A. D., Dolloff, C. A., and Harpster, K. L. 1997. Effects of large woody debris placement on stream channels and benthic macroinvertebrates. Canadian Journal of Fisheries and Aquatic Sciences 54: 931-939.

Kawaguchi, Y. and Nakano, S. 2001. Contribution of terrestrial invertebrates to the annual resource budget for salmonids in forest and grassland reaches of a headwater stream. Freshwater Biology 46:303-316.

Lestelle, L.C., M.L. Rowse, and C. Weller. 1993. Evaluation of natural stock improvement measures for Hood Canal coho salmon. Tech. Rep. No. 93-1. Point No Point Treaty Council, Kingston, Washington.

Lohr, S. C., and J. L. West. 1992. Microhabitat selection by brook and rainbow trout in a southern Appalachian stream. Transactions of the American Fisheries Society 121:729736.

MacCrimmon, H.R., and J.S. Campbell. 1969. World distribution of brook trout (Salvelinus fontinalis). Journal of the Fisheries Research Board of Canada 26:1699-1725.

Matthews, K. R. 1996. Habitat selection and movement patterns of California golden trout in degraded and recovering stream sections in the Golden Trout Wilderness, California. North American Journal of Fisheries Management 16:579-590. 
McMahon, T.E., A.V.Zales, and D.J. Orth. 1996. Aquatic habitat measurements. Pages 83108 in B.R. Murphy and D.W. Willis, editors. Fisheries techniques. American Fisheries Society, Bethesda Maryland.

Meisner, J.D. 1990. Potential effect of climate warming on the southern margins of the native distribution of brook trout, Salvelinus fontinalis. Canadian Journal of Fisheries and Aquatic Sciences 47:1065-1070.

Montgomery, D.R., and Buffington, J.M. 1997. Channel-reach morphology in mountain drainage basins. Geological Society of America Bulletin v. 109, no 5, p. 596-611.

Orth, D.J. 1983 Aquatic habitat measurements. Pages 61-84 in L.A. Nielson and D.L. Johnson, editors. Fisheries techniques. American Fisheries Society, Bethesda, Maryland.

Otis, D.L., and G.C. White. 1999. Autocorrelation of location estimates and the analysis of radiotracking data. Journal of Wildlife Management 53:1039:1044.

Overton, C.K., S.P. Wollrab, B.C. Roberts, and M.A. Radko. 1997. R1/R4 (Northern/Intermountain Regions) fish and fish habitat standard inventory procedures handbook. United States Department of Agriculture. Forest Service. Intermountain Research Station. Ogden UT. General Technical Report INT-GTR-346.

Petty, J.T., J. Freund, P.J. Lamothe \& P.M. Mazik. 2002. Quantifying the microhabitat characteristics of hydraulic channel units in the upper Shavers Fork basin. Proceedings of the Southeastern Association of Fish and Wildlife Agencies In Press.

Platts, W.S., W.F. Megahan, and G.W. Minshall. 1983. Methods for evaluating stream, riparian, and biotic conditions. U.S. Forest Service General Technical Report INT-138.

Reeves, G.H., J.O. Hall, T.D. Roelofs, T.L. Hickman, C.O. Baker. 1991. Rehabilitating and modifying stream habitats. American Fisheries Society Special Publication 19:519-557.

Rogers, K.B. 1998. Habitat use by largemouth bass and northern pike on the Rocky Mountain Arsenal, Colorado. Doctoral Dissertation. Colorado State University, Fort Collins.

Rosenfeld, J. S. and Boss, S. 2001. Fitness consequences of habitat use for juvenile cutthroat trout: energetic costs and benefits in pools and riffles. Canadian Journal of Fisheries and Aquatic Sciences 58: 585-593.

Rosenfeld, J., Porter, M., and Parkinson, E. 2000. Habitat factors affecting the abundace and distribution of juvenile cutthroat trout (Oncorhynchus clarki) and coho salmon (Oncorhynchus kisutch). Canadian Journal of Fisheries and Aquatic Sciences 57: 766774.

Rosgen, David L. 1994. A classification of natural rivers. Catena, v. 22, p. 169-199. 
Rousel, J.M., A. Bardonnet, and A. Claude. 1999. Microhabitats of brown trout when feeding on drift and when resting in a lowland salmonid brook: Effects on Weighted Usable Area. Archive for Hydrobiology 146 no. 4 p. 413-429.

Sweka, J. 2003. Aquatic-Terrestrial linkages in Appalachian streams: Effects of riparian inputs on stream habitat, brook trout populations, and trophic dynamics. West Virginia University, Morgantown, WV.

Sweka, J, and K.J. Hartman. 2002. Fall and winter brook trout prey selection and daily ration. Proceedings at the Annual Conference of Southeastern Association of Fish and Wildlife Agencies 55:8-22.

Ware, D.M. 1972. Predation by rainbow trout (Salmo gairdneri): the influence of hunger, prey density, and prey size. Journal of the Fisheries Research Board of Canada 29:1193-1201.

Winter, J.D. 1983. Underwater Biotelemety. Pages 371-396 in B.R. Murphy and D.W. Willis, editors. Fisheries techniques. American Fisheries Society, Bethesda Maryland.

Wipfli, M. S. 1997. Terrestrial invertebrates as salmonid prey and nitrogen sources in streams: contrasting old-growth and young-growth riparian forests in southeastern Alaska, U.S.A. Canadian Journal of Fisheries and Aquatic Sciences 54: 1259-1269.

Young, M.K., R.B. Rader, and T.A. Belish. 1997. Influence of macroinvertebrate drift and light on the activity and movement of Colorado River cutthroat trout. Transactions of the American Fisheries Society. 126: 428-437.

Young, M.K.1996. Summer movements and habitat use by Colorado River cutthroat trout (Oncohynchus clarki pleuriticus) in small, montane streams. Canadian Journal of Fisheries and Aquatic Sciences 53: 1403-1408.

Young, M. K. 1995. Telemetry-determined diurnal positions of brown trout (Salmo trutta) in two south-central Wyoming streams. American Midland Naturalists 133:264-273. 
Table 1: Location and movement data for the first season of tracking (May 14- June 20, 2002) for each fish determined by tag frequency.

\begin{tabular}{|c|c|c|c|c|c|c|c|c|}
\hline \multirow{2}{*}{$\begin{array}{l}\text { Fish \# } \\
\text { (freq) }\end{array}$} & \multirow{2}{*}{$\begin{array}{l}\text { Length } \\
\text { (mm) }\end{array}$} & \multirow[t]{2}{*}{ Relocations } & \multirow{2}{*}{$\begin{array}{l}\text { Unique } \\
\text { Locations }\end{array}$} & \multicolumn{2}{|c|}{ Movements (m) } & \multicolumn{3}{|c|}{ Home } \\
\hline & & & & Cumulative & St. Error & $\mathrm{Net}^{\#}$ & Range (m) & m/day \\
\hline 011 & 195 & 10 & 10 & 522.0 & 59.41 & -5.0 & 477.2 & 18.37 \\
\hline 040 & 184 & 20 & 20 & 1232.1 & 70.73 & +1013.7 & 1111.0 & 34.23 \\
\hline 071 & 209 & 18 & 16 & 4468.6 & 165.35 & +437.0 & 2681.3 & 124.13 \\
\hline 090* & 184 & 1 & 1 & - & - & - & - & - \\
\hline 110 & 168 & 20 & 9 & 273.8 & 6.54 & +109.0 & 90.3 & 7.61 \\
\hline $131+$ & 189 & 4 & 4 & - & - & - & - & - \\
\hline 151 & 188 & 21 & 20 & 1067.6 & 21.24 & +120.2 & 297.0 & 29.66 \\
\hline $171+$ & 201 & 5 & 3 & - & - & - & - & - \\
\hline $190 * *$ & 201 & 16 & 13 & 561.3 & 11.72 & +58.5 & 140.9 & 21.59 \\
\hline 211 & 187 & 15 & 14 & 1050.4 & 55.21 & +201.4 & 523.6 & 40.40 \\
\hline $241++$ & 190 & 10 & 9 & 227.0 & 10.35 & +1195.0 & 105.1 & 0.72 \\
\hline 261 & 223 & 21 & 17 & 1091.6 & 69.77 & +701.0 & 757.7 & 30.32 \\
\hline 281 & 188 & 19 & 19 & 1937.9 & 42.32 & +29.5 & 830.3 & 53.83 \\
\hline 301 & 176 & 21 & 16 & 1839.3 & 39.41 & +721.5 & 980.8 & 51.09 \\
\hline $341 * * *$ & 230 & 2 & 2 & - & - & - & - & - \\
\hline 361 & 206 & 21 & 17 & 437.4 & 10.67 & +414.5 & 136.6 & 12.15 \\
\hline 410 & 186 & 19 & 19 & 453.7 & 15.29 & +70.1 & 318.1 & 12.60 \\
\hline $451^{* *}$ & 195 & 18 & 13 & 1002.4 & 40.95 & -250.0 & 753.9 & 37.13 \\
\hline 471 & 190 & 18 & 17 & 1664.2 & 59.04 & +571.6 & 898.5 & 59.73 \\
\hline$\underline{500}$ & 196 & 21 & 13 & 354.6 & 8.53 & +10.0 & 86.3 & 9.85 \\
\hline AVG. & & & & 1136.4 & - & +337.4 & 637.4 & 33.96 \\
\hline $\begin{array}{l}\text { TOTAL } \\
* \text { Left res } \\
+ \text { Suspec } \\
* * \text { Fish c } \\
* * * \text { Tag } \\
++ \text { Expel }\end{array}$ & $\begin{array}{l}\text { arch are } \\
\text { d to hav } \\
\text { ght by f } \\
\text { tected ir } \\
\text { d tag }\end{array}$ & $\begin{array}{l}\text { (moved into F } \\
\text { gone up Roch } \\
\text { herman and t } \\
\text { woods, but no }\end{array}$ & $\begin{array}{l}\text { ocky Run). } \\
\text { y Run or cau } \\
\text { gs returned. } \\
\text { t recovered. }\end{array}$ & - & - & +5398 & - & - \\
\hline
\end{tabular}


Table 2: Location and movement data for the second season of tracking (March 27- May 8, 2003) for each fish determined by tag frequency.

\begin{tabular}{|c|c|c|c|c|c|c|c|c|}
\hline \multirow{2}{*}{$\begin{array}{l}\text { Fish \# } \\
\text { (freq) }\end{array}$} & \multirow{2}{*}{$\begin{array}{c}\text { Length } \\
(\mathrm{mm})\end{array}$} & \multirow[t]{2}{*}{ Relocations } & \multirow{2}{*}{$\begin{array}{l}\text { Unique } \\
\text { Locations }\end{array}$} & \multicolumn{2}{|c|}{ Movements (m) } & \multicolumn{3}{|c|}{ Home } \\
\hline & & & & Cumulative & St. Error & $\mathrm{Net}^{\#}$ & Range (m) & m/day \\
\hline 451 & 195 & 19 & 10 & 210.3 & 8.04 & +70.0 & 178.3 & 5.13 \\
\hline 471 & 184 & 19 & 13 & 954.3 & 23.65 & -139.2 & 318.5 & 23.28 \\
\hline 501 & 189 & 19 & 15 & 143.5 & 2.63 & +4.5 & 54.7 & 3.50 \\
\hline 561 & 197 & 20 & 13 & 390.8 & 18.53 & -294.0 & 379.0 & 9.53 \\
\hline 611 & 180 & 20 & 17 & 305.0 & 12.88 & +240.0 & 151.3 & 7.44 \\
\hline 681 & 175 & 15 & 13 & 2995.6 & 72.31 & +382.5 & 939.3 & 73.06 \\
\hline 704 & 181 & 16 & 6 & 174.0 & 4.29 & +88.0 & 83.5 & 4.24 \\
\hline 724 & 204 & 19 & 12 & 358.3 & 9.19 & +81.3 & 197.3 & 8.74 \\
\hline 744 & 201 & 21 & 10 & 8.5 & 0.24 & -1.0 & 3.5 & 0.21 \\
\hline 764 & 190 & 20 & 12 & 57.5 & 0.82 & +7.4 & 15.0 & 1.40 \\
\hline 784 & 200 & 18 & 14 & 248.5 & 6.37 & -16.5 & 125.6 & 6.05 \\
\hline 804 & 201 & 17 & 16 & 836.2 & 9.87 & -175.2 & 111.2 & 20.40 \\
\hline 824 & 159 & 17 & 16 & 2841.3 & 56.99 & -227.3 & 808.3 & 69.30 \\
\hline 844 & 185 & 20 & 8 & 77.8 & 2.29 & -42.0 & 58.4 & 1.90 \\
\hline 871 & 176 & 17 & 14 & 971.9 & 51.35 & -518.4 & 590.9 & 23.70 \\
\hline 891 & 178 & 21 & 11 & 9.2 & 0.18 & +2.8 & 3.5 & 0.22 \\
\hline 911 & 187 & 20 & 14 & 167.5 & 4.89 & +72.0 & 105.2 & 4.09 \\
\hline 931 & 185 & 18 & 17 & 2926.0 & 104.21 & -79.6 & 1395.3 & 71.37 \\
\hline 951 & 190 & 20 & 18 & 1556.5 & 20.81 & +28.5 & 425.5 & 37.96 \\
\hline$\underline{970}$ & 196 & 20 & 16 & 316.8 & 5.63 & -23.5 & 81.7 & 7.73 \\
\hline AVG. & & & & 777.0 & - & -27.0 & 301.3 & 19.96 \\
\hline TOTA & & & & & & -539.7 & & \\
\hline
\end{tabular}

\# Negative values represent down stream movement and positive values represent up stream movement. 
Table 3: Habitat variable use for the first season of tracking compared to available habitat in Birch Fork (May 14- June 20, 2002)

\section{Characteristic}

DATA SET 1 DATA SET 2 DATA SET 3

Primary habitat type

Pool (\%)

Riffle (\%)

Run (\%)

Overall

\section{Pool formation}

Boulder (\%)

Free form (\%)

LWD (\%)

Overall

\section{Cover type}

Boulder (\%)

LWD (\%)

Root wad (\%)

Under cut bank (\%)

Overall

\section{Substrate composition}

Boulder (\%)

Cobble (\%)

Pebble (\%)

Gravel (\%)

Sand (\%)

Silt (\%)

Bedrock (\%)

Overall

Distance to Bank (m)

Distance to Cover (m)

Velocity (m/s)

Depth $(\mathrm{cm})$

\% Canopy Cover

\section{Available}

Use (all)

11

71

18

a

14

71

15

a

72

16

2

10

a

19

30

28

10

9

2

2

a
41

41

18

b

\section{7}

64

19

b

75

11

8

6

b

21

27

19

11

11

1

10

a
Use (9)

45

40

15

b Use (1)

68

21

11

b 
Table 4: Habitat variable use for the second tracking season compared to available habitat in Birch Fork (March 27- May 8, 2003)

\begin{tabular}{lcccc} 
Characteristic & Available & $\begin{array}{c}\text { DATA SET 1 } \\
\text { Use (all) }\end{array}$ & $\begin{array}{c}\text { DATA SET 2 } \\
\text { Use (8) }\end{array}$ & $\begin{array}{c}\text { DATA SET } 3 \\
\text { Use (1) }\end{array}$ \\
\hline $\begin{array}{l}\text { Primary habitat type } \\
\text { Pool (\%) }\end{array}$ & 10 & 51 & 55 & 70 \\
Riffle (\%) & 58 & 17 & 13 & 5 \\
Run (\%) & 32 & 33 & 32 & 25 \\
Overall & $a$ & $b$ & $b$ & $b$ \\
Pool formation & & & & \\
$\quad$ Boulder (\%) & 37 & 23 & 19 & 14 \\
Free form (\%) & 50 & 34 & 47 & 50 \\
LWD (\%) & 13 & 43 & 34 & 36 \\
Overall & $a$ & $b$ & $b$ & $b$ \\
Cover type & & & & \\
Boulder (\%) & 75 & 56 & 57 & 55 \\
LWD (\%) & 17 & 29 & 30 & 40 \\
Root wad (\%) & 2 & 11 & 10 & - \\
Under cut bank (\%) & 6 & 4 & 3 & 5 \\
Overall & $a$ & $b$ & $b$ & $a$
\end{tabular}

\section{Substrate composition}

Boulder (\%)

Cobble (\%)

Pebble (\%)

Gravel (\%)

Sand $(\%)$

Silt (\%)

Bedrock (\%)

Organic (\%)

Overall

16

27

28

15

7

2

4

1

a
14

28

25

16

9

3

4

$<1$

a

\section{6}

26

22

16

10

3

6

0

a
23

30

21

10

5

2

5

0

a

Distance to Bank (m)

$1.16^{a}$

$1.55^{b}$

$1.36^{b}$

$1.48^{b}$

Distance to Cover (m)

$1.32^{a}$

Velocity $(\mathrm{m} / \mathrm{s})$

$0.255^{a}$

Depth $(\mathrm{cm})$

$14.9^{a}$

$0.74^{b}$

$0.71^{b}$

$0.69^{b}$

$0.170^{b}$

$0.164^{b}$

$35.7^{b}$

$38.3^{b}$

$0.207^{a}$

$38.5^{b}$

Note: For comparisons between available and used habitats, overall values with letters not in common are significantly different. 
Table 5: Habitat variable use for high flow $\left(>0.35 \mathrm{~m}^{3} / \mathrm{s}\right)$ and non-high flow events from second season (2003). High flows were determined from daily discharge.

\section{Characteristic Use at High Flows Use at Non-High Flows}

\section{Primary habitat type}

Pool (\%)

Riffle (\%)

Run (\%)

Overall

\section{Pool formation}

Boulder (\%)

Free form (\%)

LWD (\%)

Overall

Cover type

Boulder (\%)

LWD (\%)

Root wad (\%)

Under cut bank (\%)

Overall

\section{Substrate composition}

Boulder (\%)

Cobble (\%)

Pebble (\%)

Gravel (\%)

Sand $(\%)$

Silt (\%)

Bedrock (\%)

Overall

Distance to Bank (m)

Distance to Cover (m)

Velocity $(\mathrm{m} / \mathrm{s})$

Depth (cm)
55

18

27

a

24

38

38

a

51

31

14

4

a

16

24

23

15

11

3

6

a

$1.43^{\mathrm{a}}$

$0.71^{\mathrm{a}}$

$0.165^{\mathrm{a}}$

$38.1^{\mathrm{a}}$
59

9

32

b

21

29

50

b

60

35

4

1

b

\section{7}

32

21

15

9

3

3

a

$1.31^{\mathrm{b}}$

$0.56^{\mathrm{b}}$

$0.355^{\mathrm{b}}$

$36.0^{\mathrm{b}}$

Note: For comparisons between non-high flow event and high flow event habitat use, overall values with letters not in common are significantly different. 
Figure 1: The Birch Fork study site part of the Middle Fork River Watershed, Randolph County, West Virginia.

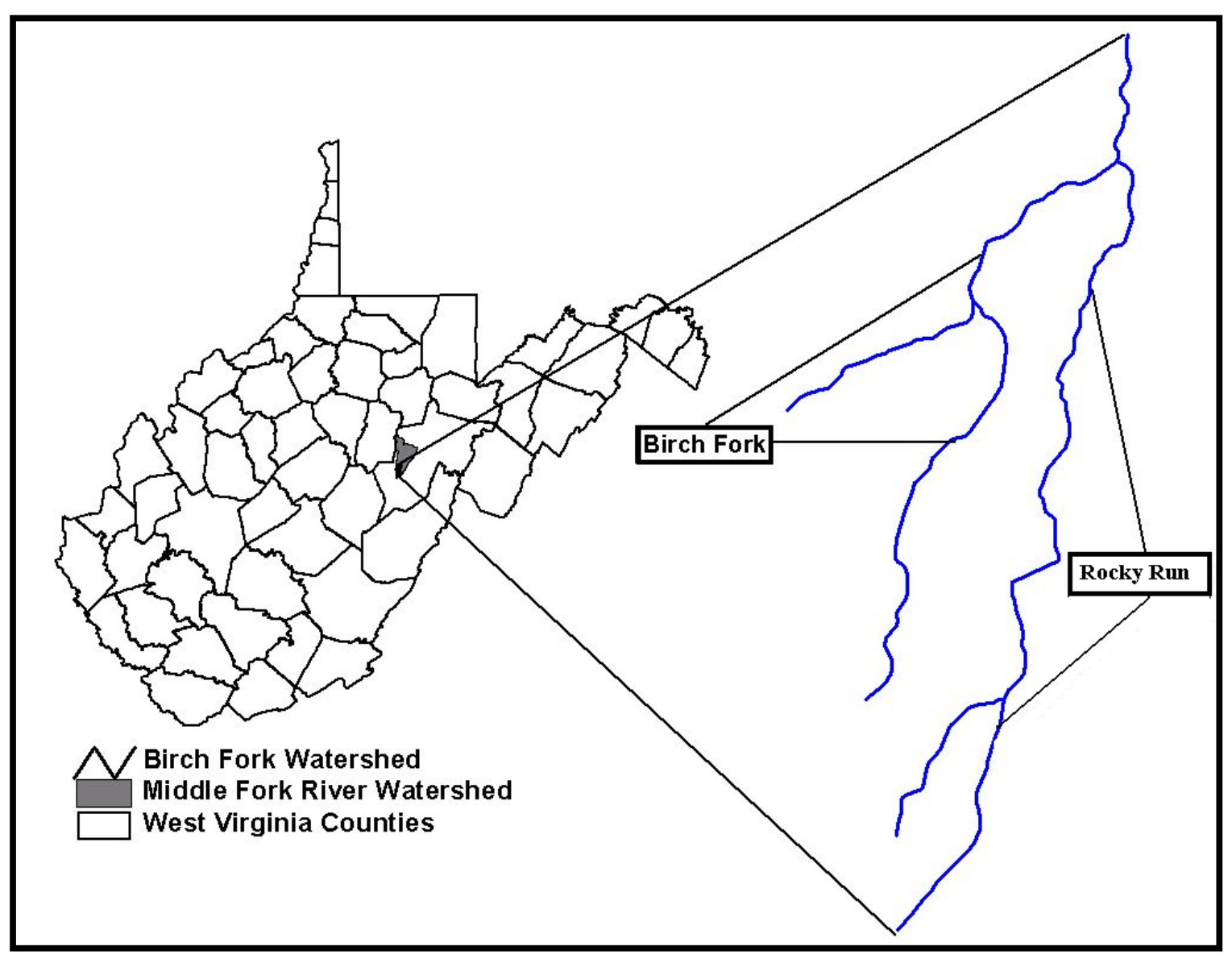




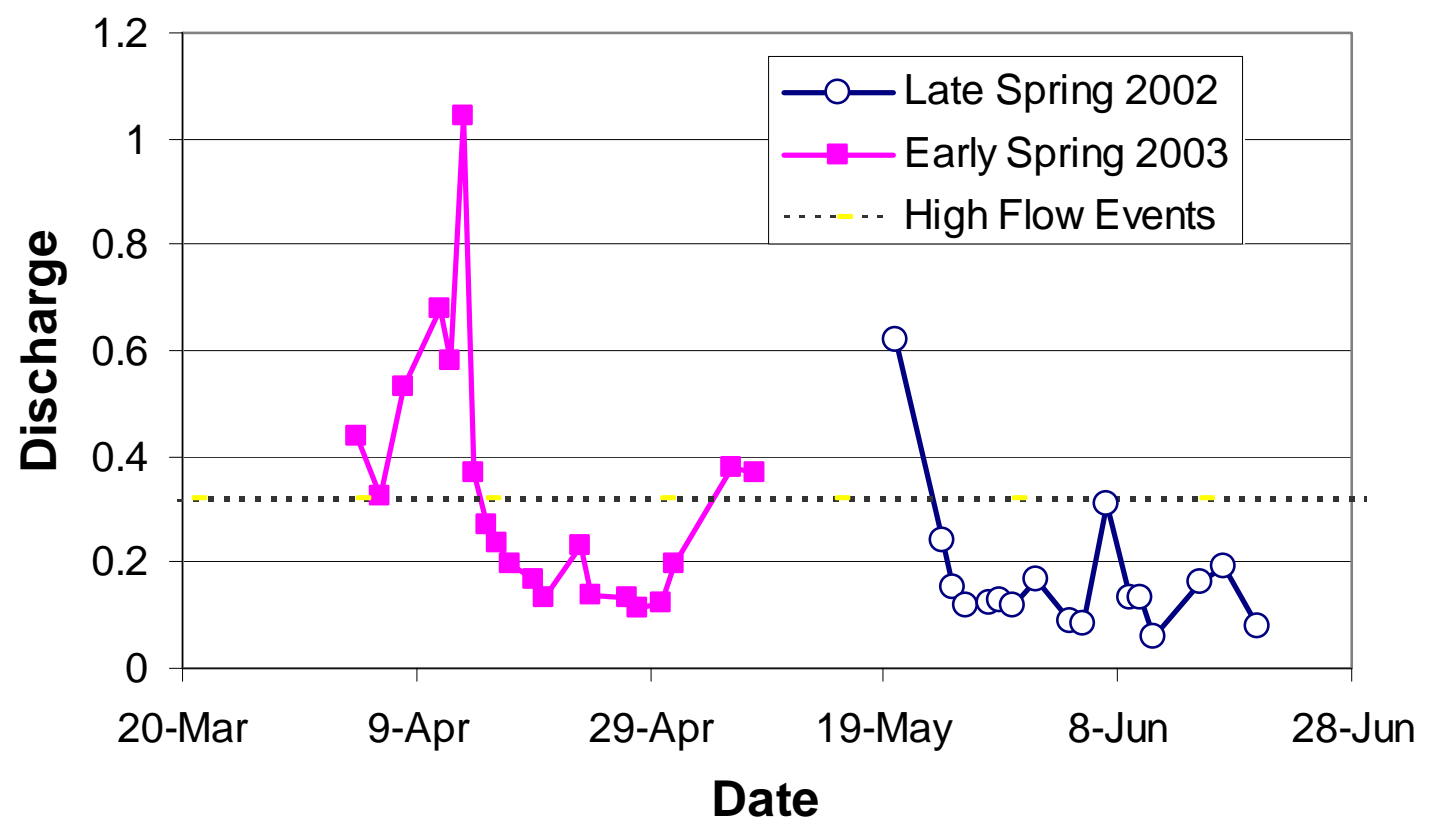

Figure 2: Discharge measurements at the lower study reach of Birch Fork during the 2002 and 2003 tracking season. Discharge from the 2003 season was used to determine high flow events. 


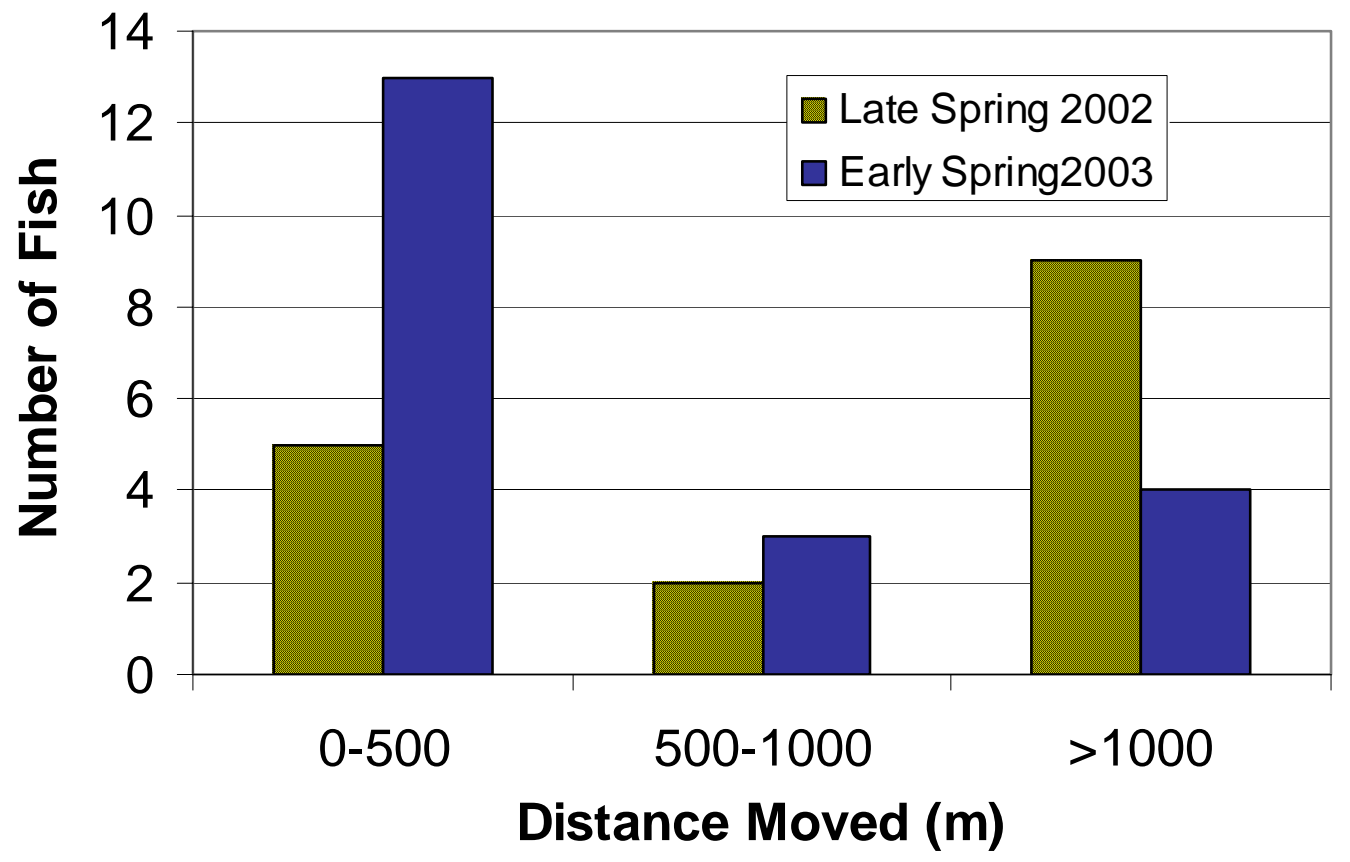

Figure 3: Histogram of total distance moved by brook trout in Birch Fork during the 2002 and 2003 tracking period. 


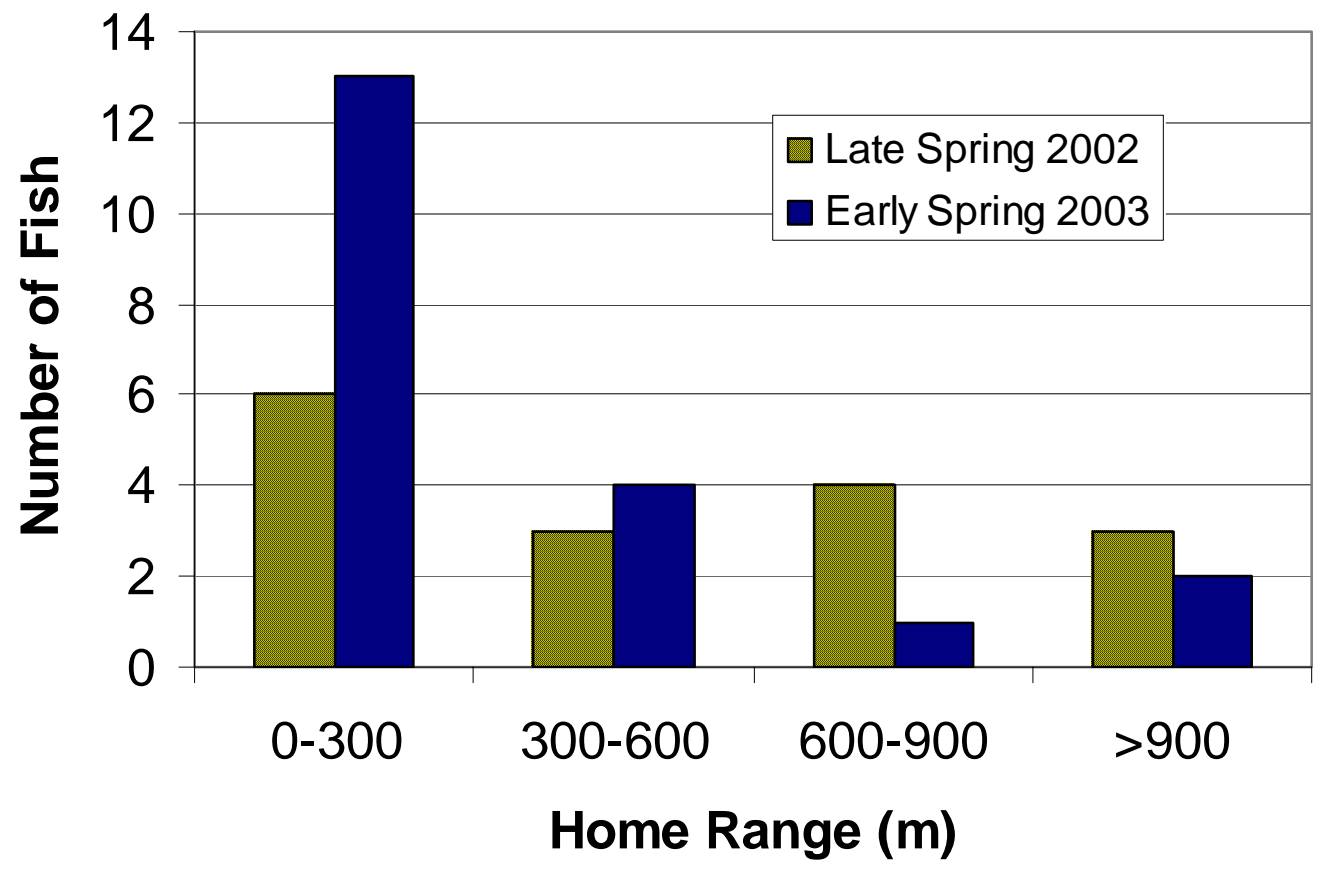

Figure 4: Histogram of home range lengths for brook trout in Birch Fork during the 2002 and 2003 tracking period. 

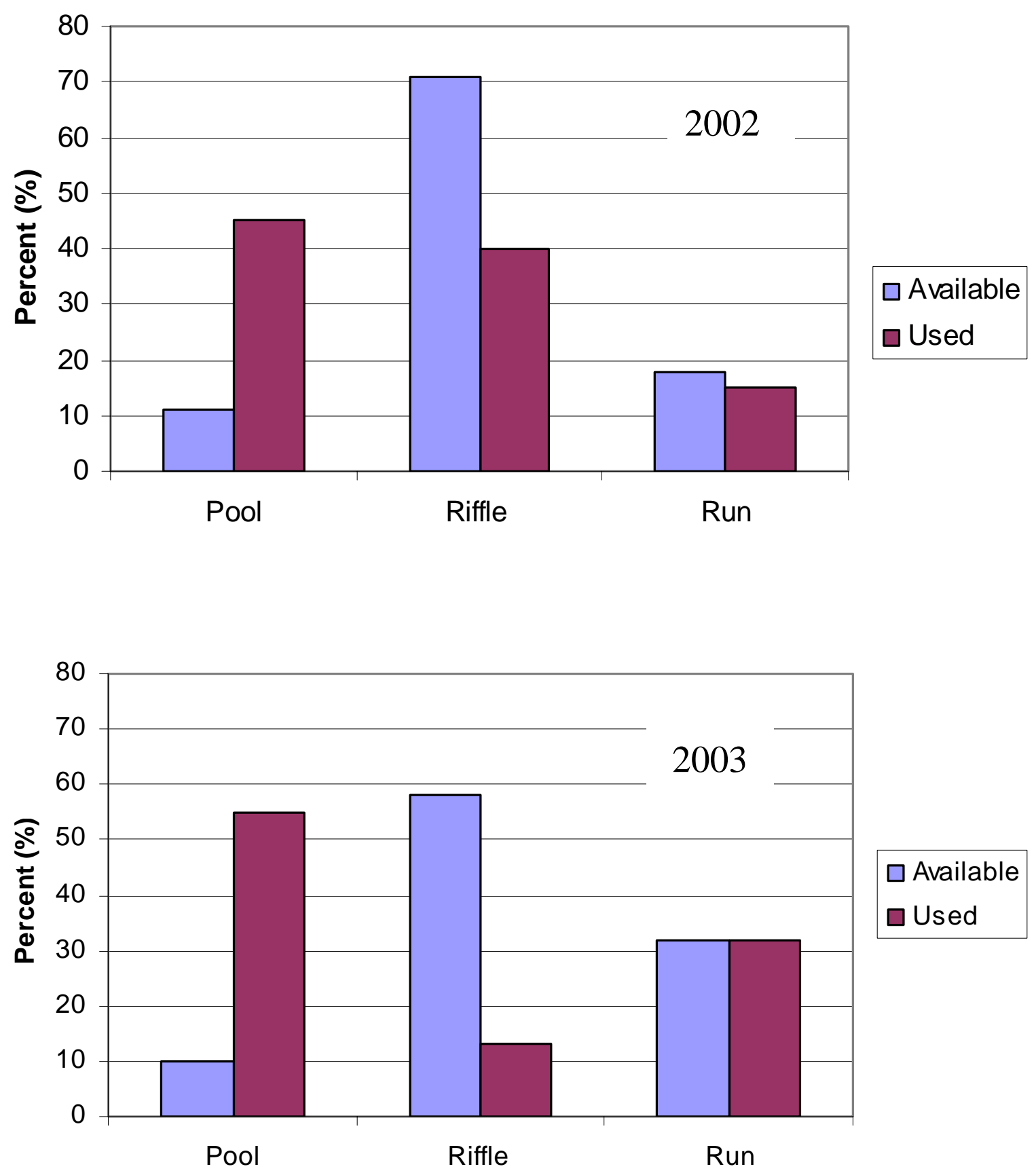

Figure 5: Brook trout use vs. available primary habitat during 2002 and 2003 tracking. 

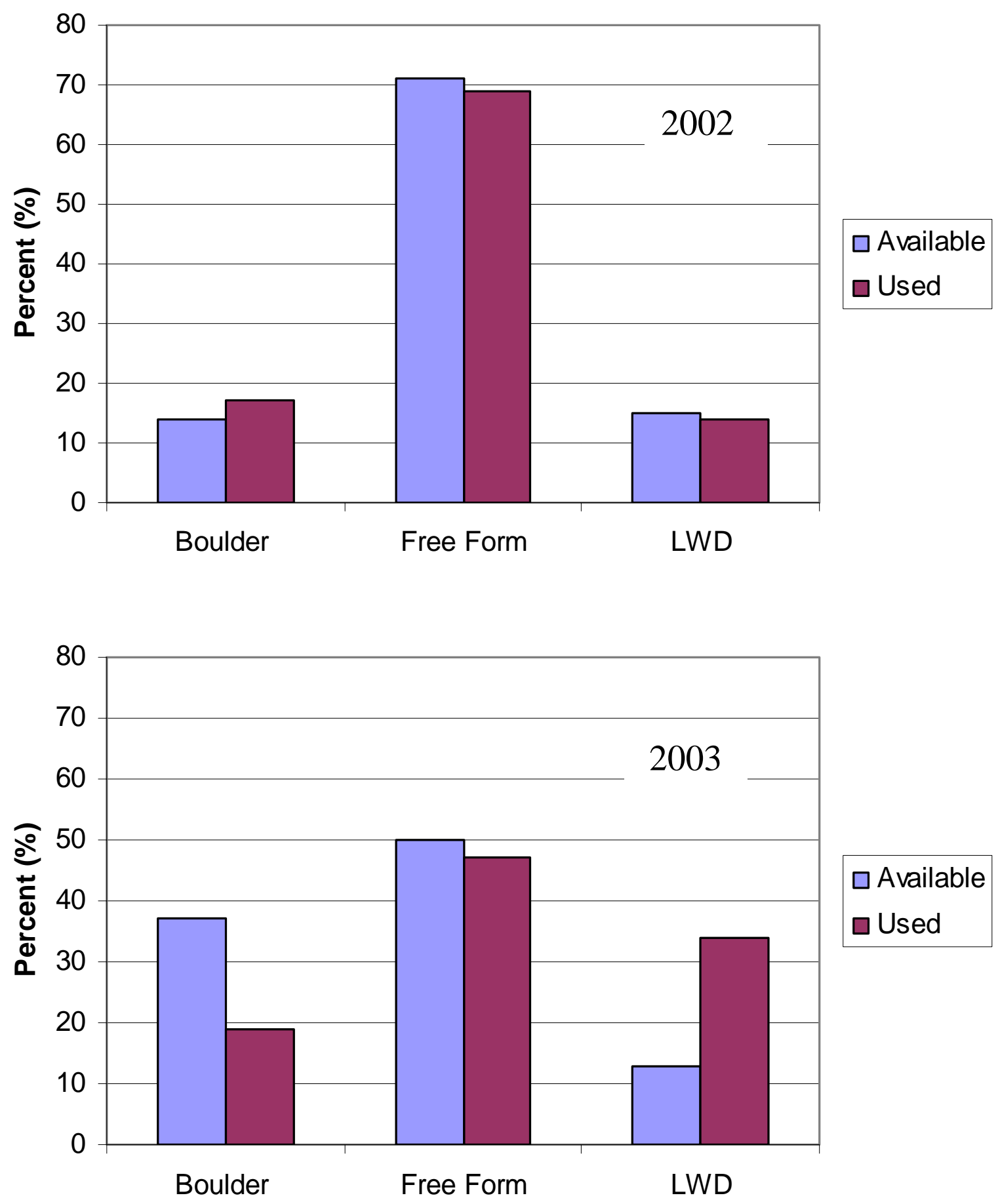

Figure 6: Brook trout use vs. available pool forming structures during 2002 and 2003 tracking. 

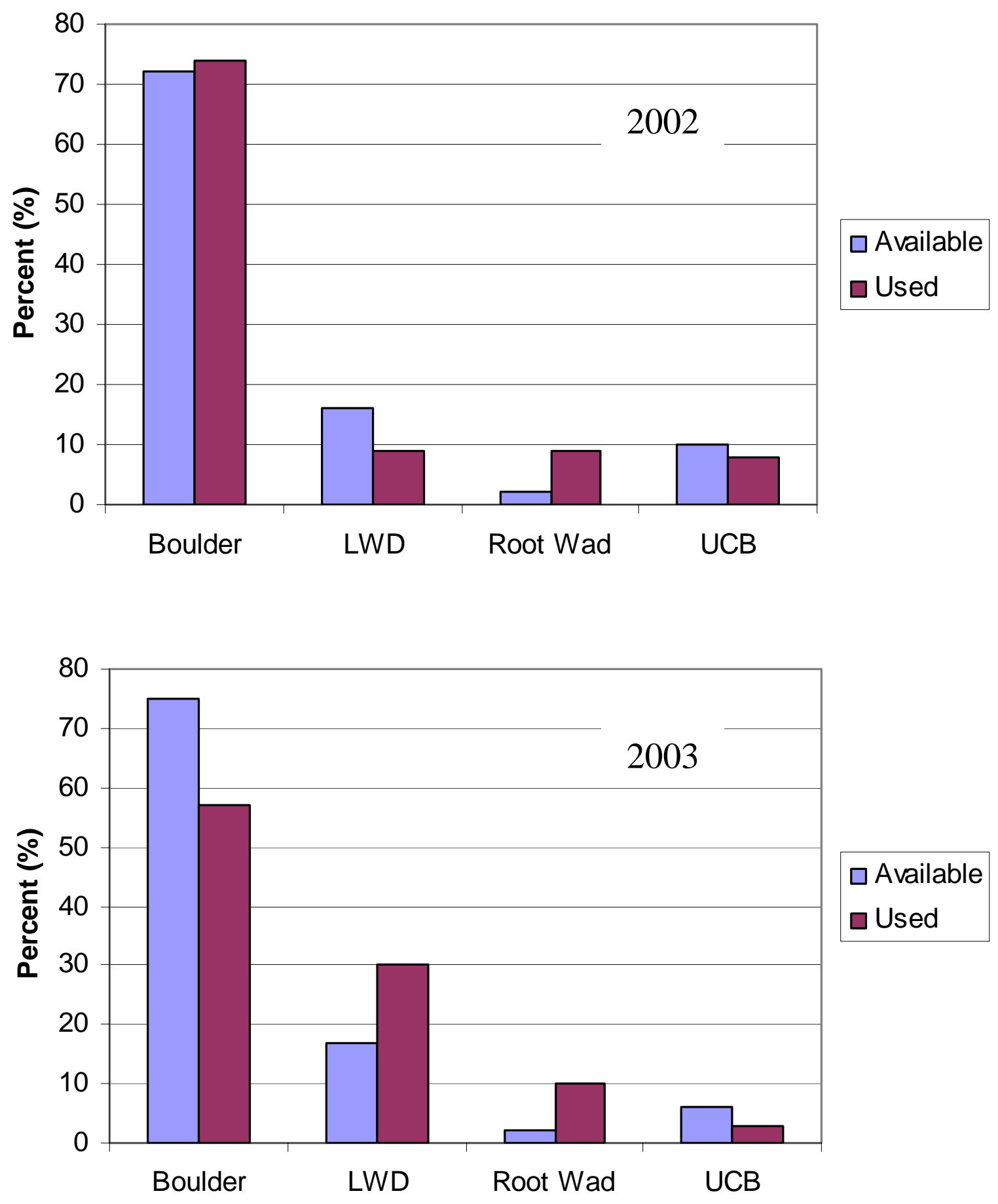

Figure 7: Brook trout use vs. available cover type during 2002 and 2003 tracking. 

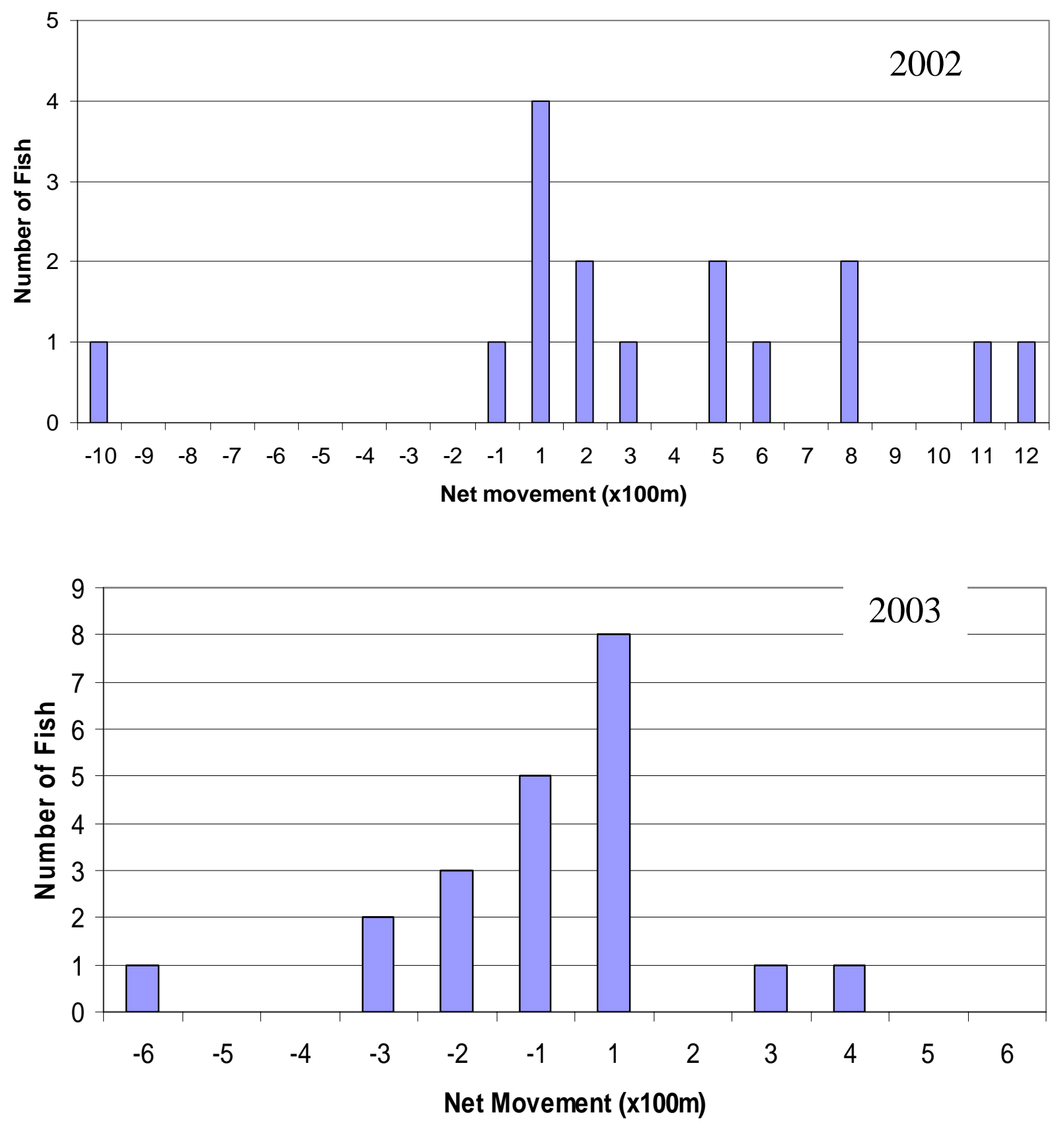

Figure 8: Net movement histogram for the 2002 and 2003 tracking season. Net movement was considered the distance from original placement to final tracking location. Negatives values represent a net down stream movement and positive values represent a net up stream movement. 

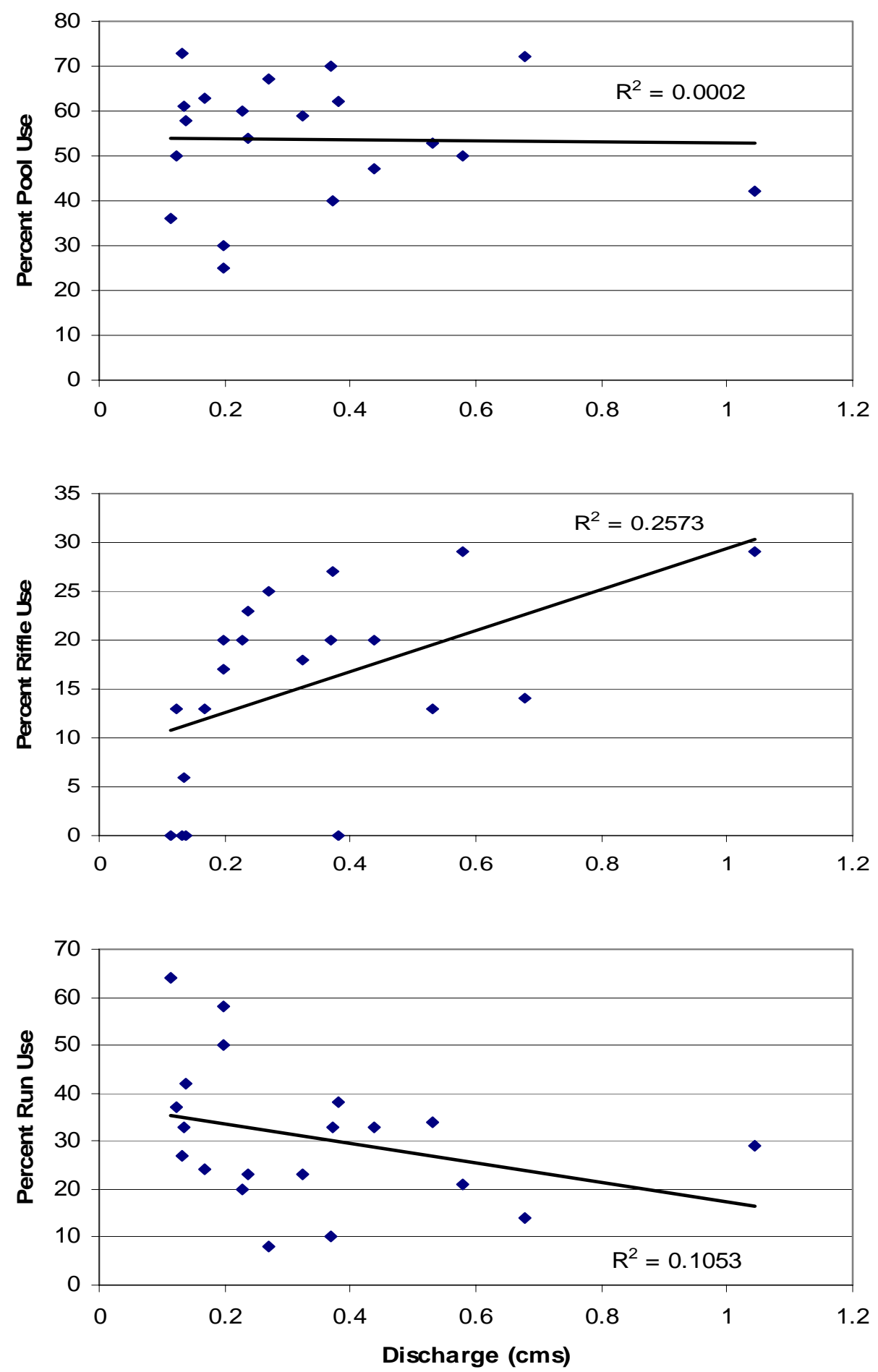

Figure 9: Percent primary habitat use at varying discharge (2003). Percent riffle use seems to increase as discharge increases. This agrees with the high flow event vs. non-high flow event primary habitat use found in 2003. 

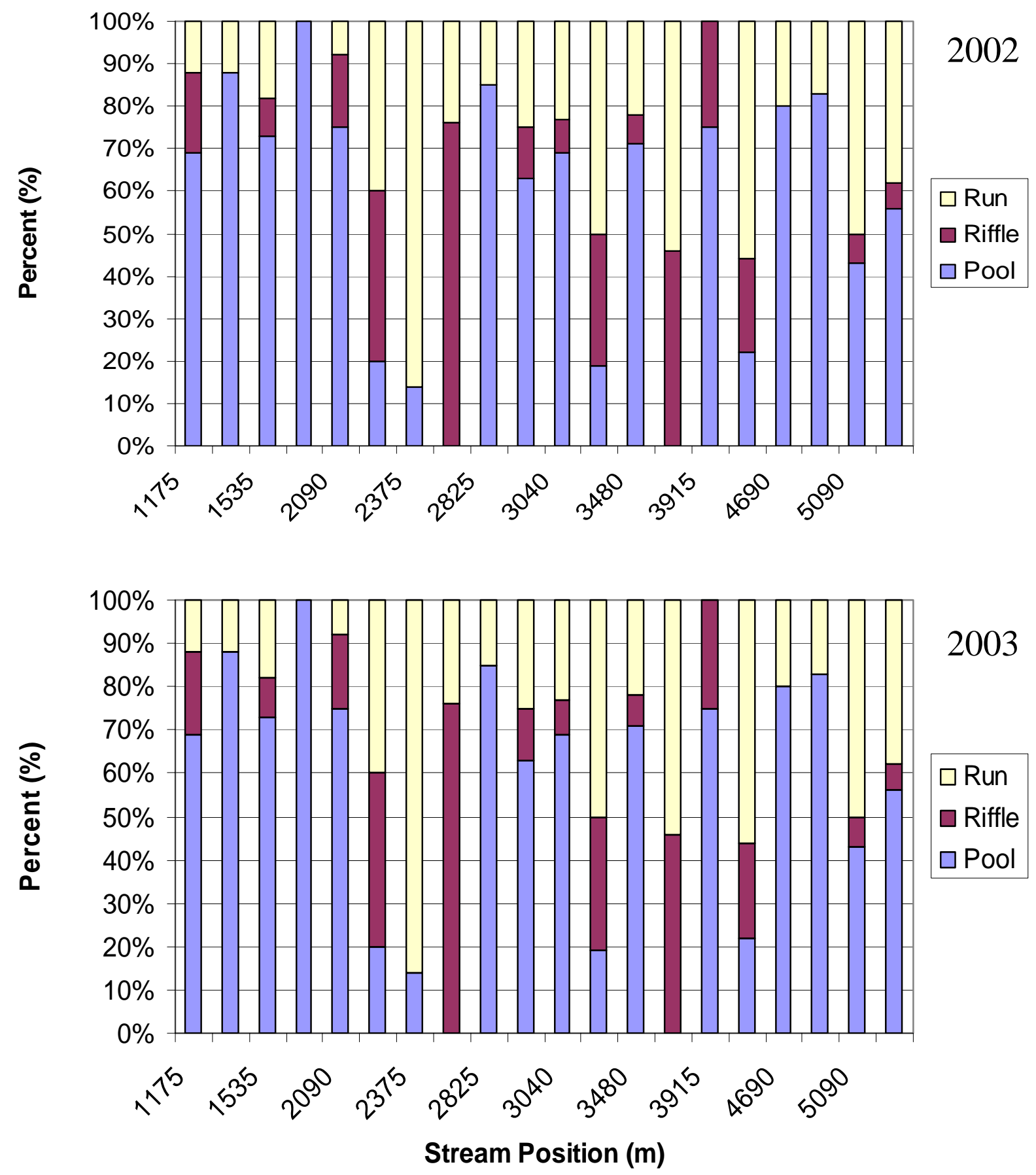

Figure 10: Primary habitat use for 2002 and 2003 broken down by individual fish versus where they were first placed in Birch Fork. 

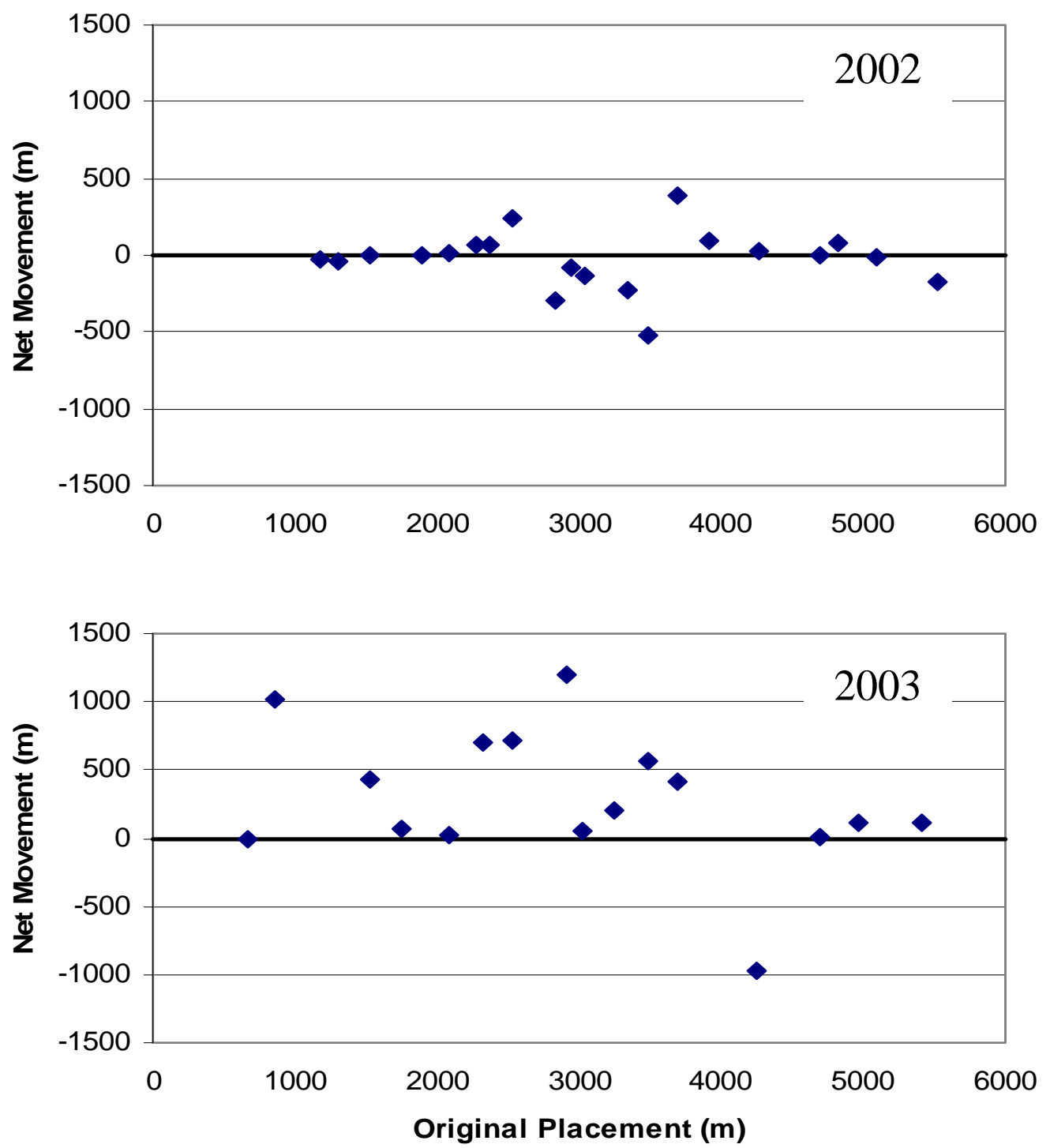

Figure 11: Individual fish net movement (2002 and 2003) compared to where they were originally placed in Birch Fork. 


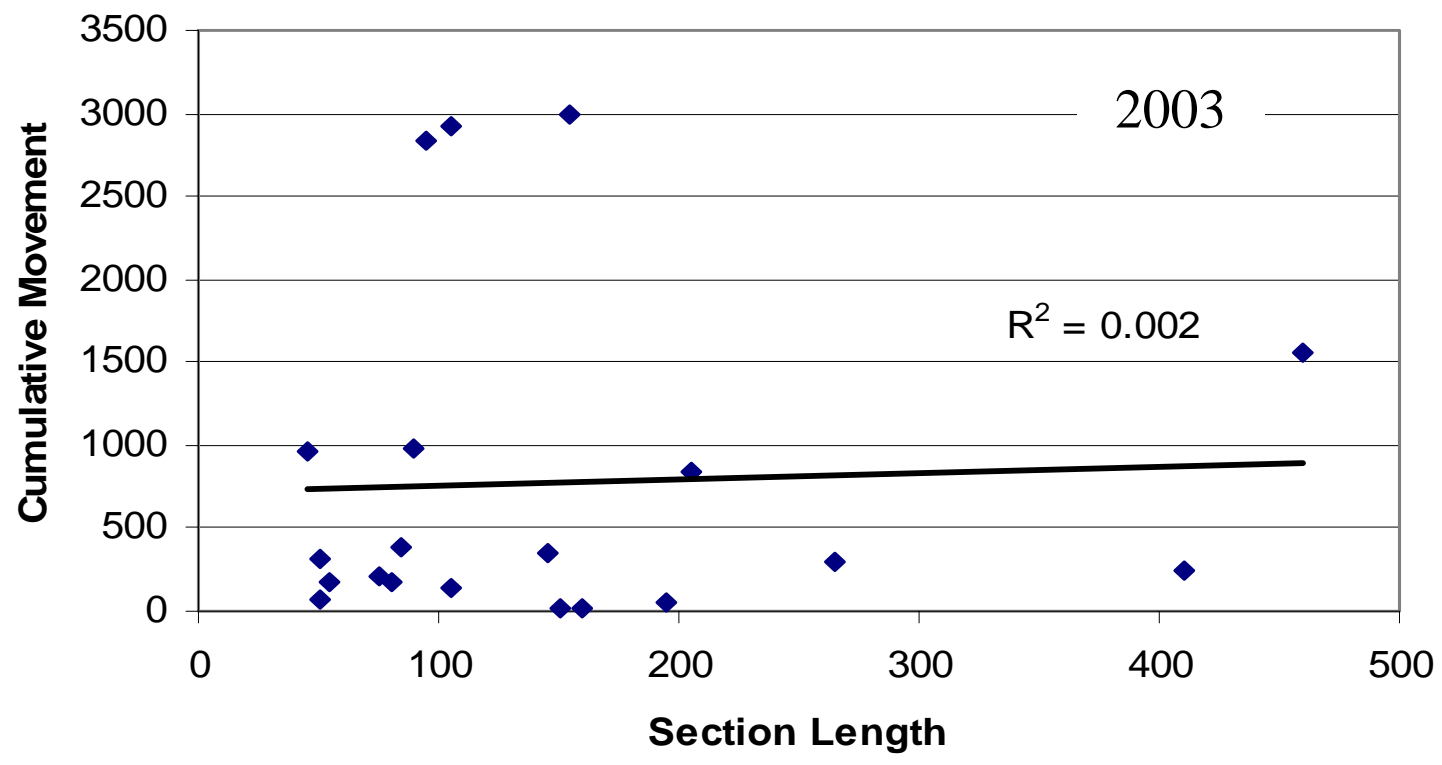

Figure 12: There was no link between section length (representing habitat complexity) and movement. 
Marisa Nel Logan

1412 Fairfield St. \#10

Morgantown, WV 26505

(304)598-2379

email: dmb1212@hotmail.com

\section{Education}

MS Fisheries Management (Dec. 2003) West Virginia University, Morgantown, WV 26506, Major advisor: Dr. Kyle Hartman

BS Environmental Science, minor in Chemistry (2001) Waynesburg College, Waynesburg, PA 15370

Graduate Courses:

Statistical Methods $1 \& 2$

Intro to Fisheries Management

Forest Limnology

Fisheries Technique

Advanced Ichthyology

Spatial Analysis for RESM (GIS)

Aquatic Toxicology

Rivers/Floods/Landslides

Quantitative Ecology

Wildlife Seminar

\section{Professional Experience:}

June 2001 to present: Research Assistant, Fish and Wildlife Management Department, West Virginia University, Morgantown, WV

Duties: Stream Electrofishing

River Electrofishing

Stream Telemetry

Implant Surgeries

Setting Drift Nets

Fin Clipping

PIT Tagging

Picking Invertebrates from drift samples using a microscope

Data Analysis using Excel and SAS

Data Entry from data sheets using Excel

August 2001 to December 2002: Teaching Assistant, Biology Department, West Virginia University, Morgantown, WV 
Summer 1999 and 2000: Global Change Education Program DOE Internship, Oak Ridge National Lab, Oak Ridge, TN

\section{Training and Workshops}

First Aid and CPR

MOCC

\section{Professional Memberships}

American Fisheries Society

\section{Presentations}

Logan, M.N., K. Hartman. 2003. Influence of Habitat Quality on Brook Trout (Salvelinus fontinalis) Movement. Wildlife Seminar, West Virginia University. March 5, 2003.

Logan, M.N. 2002. Morphometric Comparisons of the Atlantic and Mississippi Drainage Central Stoneroller (Campostoma anomalum). Advanced Ichthyology Class, West Virginia University. November 2002.

Jenkins, M.N., K. Hartman. 2002. Research Proposal: Brook Trout (Salvelinus fontinalis) Habitat Use and Movement. Wildlife Seminar, West Virginia University. April 23, 2002.

Jenkins, M.N. 1999. Sweet Gum Respiration Rates in Elevated $\mathrm{CO}_{2}$ Environment. Waynesburg College. September 1999. 